Water Availability and Use Science Program

Estimates of Water Use Associated with Continuous Oil and Gas Development in the Permian Basin, Texas and New Mexico, 2010-19

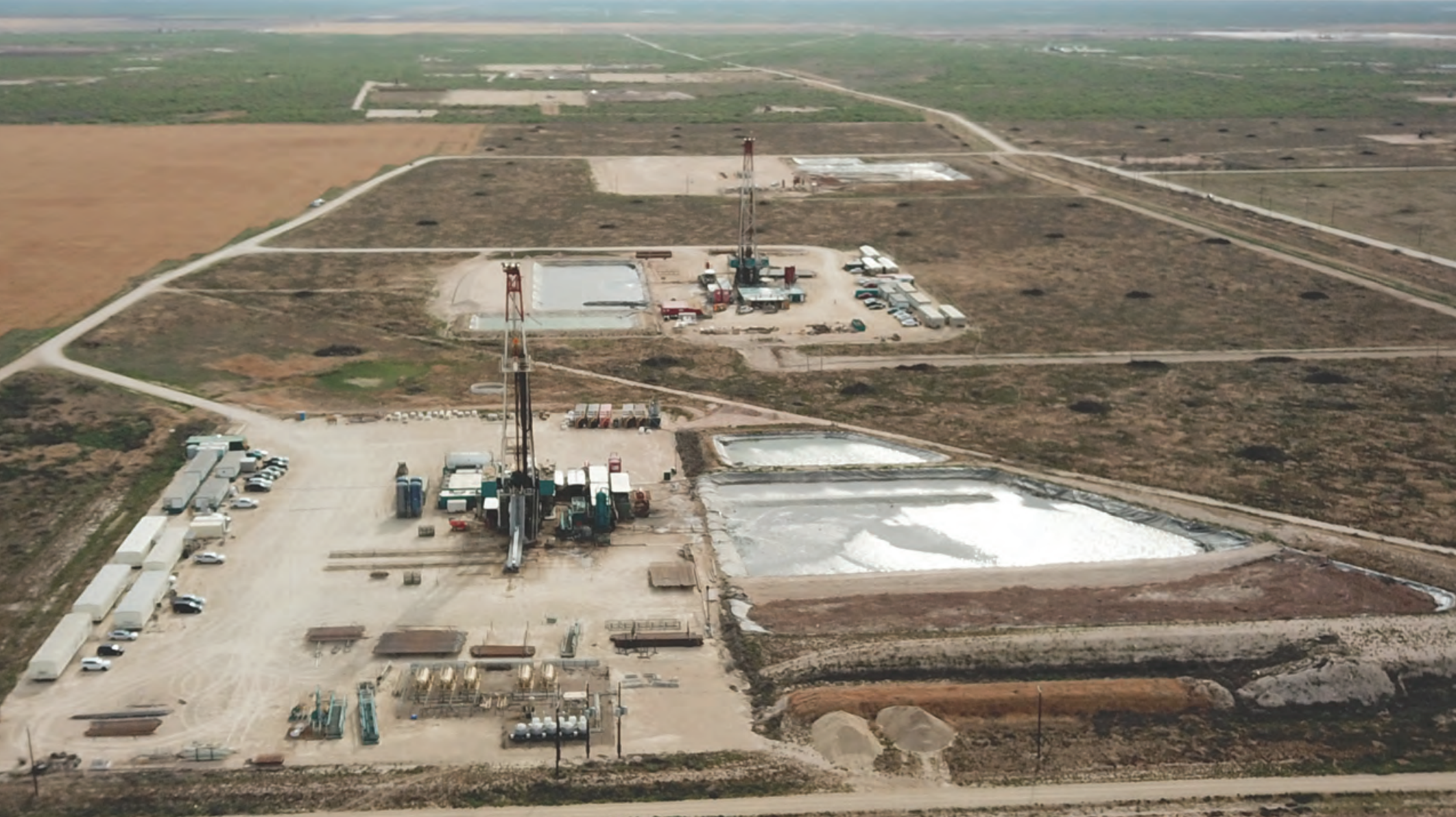

Scientific Investigations Report 2021-5090 
Covers: Photographs showing (front cover) continuous oil and gas operations with two active drilling rigs in the Permian Basin, taken near Midland, Texas, on May 14, 2020, and (back cover) a temporary freshwater source used in well completion operations next to a well site with oil and gas infrastructure equipment in the Permian Basin, taken near Loving, Texas, on May 15, 2020. Photographs by Jared Hindman, used with permission. 


\section{Estimates of Water Use Associated with Continuous Oil and Gas Development in the Permian Basin, Texas and New Mexico, 2010-19}

By Joshua F. Valder, Ryan R. McShane, Joanna N. Thamke, Jeremy S. McDowell, Grady P. Ball, Natalie A. Houston, and Amy E. Galanter

Water Availability and Use Science Program

Scientific Investigations Report 2021-5090 


\section{U.S. Geological Survey, Reston, Virginia: 2021}

For more information on the USGS - the Federal source for science about the Earth, its natural and living resources, natural hazards, and the environment—visit https://www.usgs.gov or call 1-888-ASK-USGS.

For an overview of USGS information products, including maps, imagery, and publications, visit https://store.usgs.gov/.

Any use of trade, firm, or product names is for descriptive purposes only and does not imply endorsement by the U.S. Government.

Although this information product, for the most part, is in the public domain, it also may contain copyrighted materials as noted in the text. Permission to reproduce copyrighted items must be secured from the copyright owner.

Suggested citation:

Valder, J.F., McShane, R.R., Thamke, J.N., McDowell, J.S., Ball, G.P., Houston, N.A., and Galanter, A.E., 2021, Estimates of water use associated with continuous oil and gas development in the Permian Basin, Texas and New Mexico, 2010-19: U.S. Geological Survey Scientific Investigations Report 2021-5090, 27 p., https://doi.org/10.3133/ sir20215090.

Associated data for this publication:

Ball, G.P., Galanter, A.E., McDowell, J.S., Houston, N.A., McShane, R.R., Haines, S., Varela, B., Valder, J.F., and Thamke, J.N., 2020, Data to estimate water use associated with continuous oil and gas development, Permian Basin, United States, 1980-2019: U.S. Geological Survey data release, https://doi.org/10.5066/PGLAWIPH.

Dutton, D.M., Varela, B., Haines, S.S., Barnhart, T.B., McShane, R.R., and Wheeling, S.L., 2019, Data to estimate water use associated with continuous oil and gas development, Williston Basin, United States, 1980-2017 (ver. 2.0, September 2019): U.S. Geological Survey data release, https://doi.org/10.5066/P9CPKRLW.

McShane, R.R., and McDowell, J.S., 2021, R scripts and results of estimated water use associated with continuous oil and gas development, Permian Basin, United States, 2010-19: U.S. Geological Survey data release, https://doi. org/10.5066/P9JIOU3V.

U.S. Geological Survey, 2020, USGS water data for the Nation: U.S. Geological Survey National Water Information System database, https://doi.org/10.5066/F7P55KJN.

ISSN 2328-0328 (online) 


\section{Acknowledgments}

The authors thank State and local officials from Texas and New Mexico for their support of past and ongoing projects that provided valuable information for this study.

This study was supported by the U.S. Geological Survey Water Availability and Use Science Program. The authors thank U.S. Geological Survey colleagues for their thoughtful edits and comments in reviewing this report, and Jana Stewart and Mindi Dalton, for their helpful guidance as members of the project management team. 



\section{Contents}

Acknowledgments ……...................................................................................................................





Description of Study Area ..................................................................................................2

History of Oil and Gas Development in the Permian Basin.................................................4

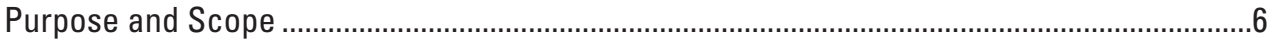

Methods for Analyzing Water Use ...............................................................................................

Procedures for Processing Data for Analysis .......................................................................

Procedures for Modeling Water Use and Uncertainty.............................................................

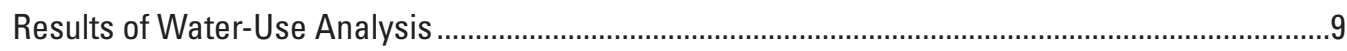

Estimates of Water Use by County and Year ..........................................................................

Coefficients of Water Use per Developed Oil and Gas Well ....................................................13

Performance of Regression Models of Water Use ...................................................................16

Comparisons to Water-Use Estimates from Other Studies................................................................18

Comparison with Water-Use Analysis of the Williston Basin .......................................................21

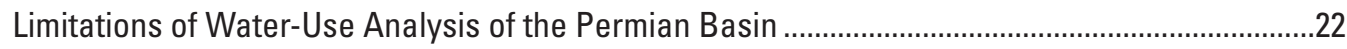

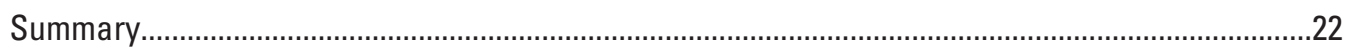

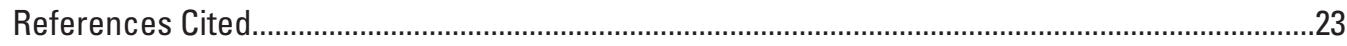

\section{Figures}

1. Map showing location of the Permian Basin, Permian Basin structural features, and Texas and New Mexico counties within the study area .............................................

2. Generalized geologic cross section characterizing the stratigraphic sequence of the Permian Basin .........................................................................................................

3. Schematic showing various water and energy features of conventional and continuous oil and gas development in the Midland Basin of the Permian Basin .............5

4. Graph showing number of production wells and volume of oil production in the Permian Basin in Texas from 1935 to 2018 and volume of oil production in New Mexico from 1923 to 2019

5. Graphs showing annual estimates from linear regression models of direct, indirect, and ancillary water use in the Permian Basin from 2010 to 2019 in Texas and New Mexico

6. Graphs showing mean annual estimates from linear regression models of direct, indirect, and ancillary water use by county in the Permian Basin from 2010 to 2019 in Texas and New Mexico

7. Graph showing linear regression model of population as explained by number of oil and gas wells developed per year in the Permian Basin.

8. Graphs showing annual estimates of direct, indirect, and ancillary water use in the Permian Basin from 2010 to 2019 for hydraulic fracturing and ancillary uses and indirect, drilling, and cementing uses

9. Graphs showing linear and quantile regression models of direct, indirect, and ancillary water use as explained by number of oil and gas wells developed per sampling unit for the Permian Basin 
10. Graphs showing relation between observed and estimated direct, indirect, and ancillary water use per sampling unit as mean values from linear regression models for the Permian Basin

11. Graphs showing annual estimates of direct, indirect, and ancillary water use in the Williston Basin from 2010 to 2017 and the Permian Basin from 2010 to 2019

\section{Tables}

1. Information and data sources used to estimate direct, indirect, and ancillary water use associated with continuous oil and gas development in the Permian Basin

2. Mean annual estimates from linear and quantile regression models of direct and indirect, ancillary, and other potential ancillary water use associated with continuous oil and gas development in the Permian Basin

3. Coefficients from linear and quantile regression models of direct and indirect, ancillary, and other potential ancillary water use per oil and gas well developed in the Permian Basin

4. Goodness-of-fit metrics from leave-one-out cross validation of linear regression models of direct, indirect, and ancillary water use per oil and gas well developed in the Permian Basin

5. Annual per-well estimates of direct, indirect, and ancillary water use for the Permian Basin in New Mexico and Texas from 2010 to 2019

6. Annual per-well estimates of direct water use associated with continuous oil and gas development in the Permian Basin from other studies

\section{Conversion Factors}

U.S. customary units to International System of Units

\begin{tabular}{|c|c|c|}
\hline Multiply & By & To obtain \\
\hline \multicolumn{3}{|c|}{ Length } \\
\hline foot $(\mathrm{ft})$ & 0.3048 & meter $(\mathrm{m})$ \\
\hline mile (mi) & 1.609 & kilometer $(\mathrm{km})$ \\
\hline \multicolumn{3}{|c|}{ Area } \\
\hline square mile $\left(\mathrm{mi}^{2}\right)$ & 259.0 & hectare (ha) \\
\hline square mile $\left(\mathrm{mi}^{2}\right)$ & 2.590 & square kilometer $\left(\mathrm{km}^{2}\right)$ \\
\hline \multicolumn{3}{|c|}{ Volume } \\
\hline barrel (bbl; petroleum, 1 barrel=42 gal) & 0.1590 & cubic meter $\left(\mathrm{m}^{3}\right)$ \\
\hline gallon (gal) & 3.785 & liter $(\mathrm{L})$ \\
\hline gallon (gal) & 0.003785 & cubic meter $\left(\mathrm{m}^{3}\right)$ \\
\hline million gallons (Mgal) & 3,785 & cubic meter $\left(\mathrm{m}^{3}\right)$ \\
\hline cubic foot $\left(\mathrm{ft}^{3}\right)$ & 0.02832 & cubic meter $\left(\mathrm{m}^{3}\right)$ \\
\hline \multicolumn{3}{|c|}{ Mass } \\
\hline pound, avoirdupois (lb) & 0.4536 & kilogram $(\mathrm{kg})$ \\
\hline
\end{tabular}


International System of Units to U.S. customary units

\begin{tabular}{lccc}
\hline & Multiply & By & To obtain \\
\hline & Length & \\
\hline kilometer $(\mathrm{km})$ & 0.6214 & mile $(\mathrm{mi})$ \\
\hline
\end{tabular}

\section{Datum}

Vertical coordinate information is referenced to the North American Vertical Datum of 1988 (NAVD 88).

Horizontal coordinate information is referenced to the North American Datum of 1983 (NAD 83).

Altitude, as used in this report, refers to distance above the vertical datum.

\section{Supplemental Information}

Water use is given in million gallons per year (Mgal/yr) or million gallons (Mgal) per well.

\section{Abbreviations}

$\begin{array}{ll}\text { COG } & \text { continuous oil and gas } \\ R^{2} & \text { coefficient of determination } \\ \text { RMSE } & \text { root mean square error } \\ \text { RSR } & \text { ratio of root mean square error to standard deviation of observations } \\ \text { USGS } & \text { U.S. Geological Survey }\end{array}$





\title{
Estimates of Water Use Associated with Continuous Oil and Gas Development in the Permian Basin, Texas and New Mexico, 2010-19
}

\author{
By Joshua F. Valder, Ryan R. McShane, Joanna N. Thamke, Jeremy S. McDowell, Grady P. Ball, Natalie A. \\ Houston, and Amy E. Galanter
}

\section{Abstract}

In 2015, the U.S. Geological Survey started a topical study to quantify water use in areas of continuous oil and gas (COG) development. The first phase of the study was completed in 2019 and analyzed the Williston Basin. The second phase of the study analyzed the Permian Basin using the same techniques and approaches used for the Williston Basin analysis. The Permian Basin was selected for the second phase of water-use analysis for the following reasons: (1) the basin has the largest undiscovered technically recoverable oil and gas resource in the United States, (2) the basin has a continuous resource in tight shale that primarily produces oil, and (3) the basin is within the contiguous United States. This study used data from 60 counties in Texas and New Mexico with spatial coverage based on the Permian Basin extent defined by the U.S. Energy Information Administration, a representation of the geologically defined Permian Basin.

Data from several sources were used in the analysis of direct, indirect, and ancillary water use associated with COG development in the Permian Basin and are available in an associated data release. Hydraulic fracturing water-use data were used to determine the start of the recent (before 2019) COG development boom in oil production in the Permian Basin in the same way that the data were used for the Williston Basin study. Water-use data were aggregated by county and year, which were the sampling units used in the analysis.

The water-use analysis of the Permian Basin contained three elements: (1) estimates of water use, in million gallons, by county and year; (2) coefficients of water use from regression models, in million gallons per developed oil and gas well; and (3) performance (based on goodness-of-fit metrics) of the regression models in estimating the observed water use.

Coefficients from the linear and quantile regression models of direct, indirect, and ancillary water use in the Permian Basin were produced as aggregate values for the counties and years. The mean estimate of direct water use had a 95-percent confidence interval of 4.13-5.45 million gallons (Mgal) per developed oil and gas well. The coefficient from the linear regression model of indirect water use was
0.111 Mgal per well, with a 95-percent confidence interval of 0.104-0.117 Mgal per well. The mean estimate of ancillary water use in the Permian Basin was 1.09 Mgal per well, with a 95-percent confidence interval of 1.05-1.13 Mgal per well. Model performance was evaluated with goodness-of-fit metrics including coefficient of determination $\left(R^{2}\right)$, root mean square error, and the ratio of root mean square error to standard deviation of observations computed from leave-one-out cross validation of the linear and quantile regression models of direct, indirect, and ancillary water use. Model performance for direct water use was acceptable, with an $R^{2}$ value of 0.91 . The model performance of indirect water use was acceptable, with an $R^{2}$ value of 0.89 . Values of $R^{2}$ for the ancillary wateruse categories were at least 0.89 .

Annual mean estimates for hydraulic fracturing, cementing, drilling, indirect, and ancillary water use per well for the years 2010-17 were comparable between the Permian and Williston Basins. Hydraulic fracturing water use increased similarly from 2010 to 2015 in the Permian Basin and the Williston Basin, increasing from 0.6 Mgal per well in 2010 to $5.4 \mathrm{Mgal}$ per well in 2015 in the Permian Basin and from 1.4 Mgal per well in 2010 to 4.7 Mgal per well in 2015 in the Williston Basin.

By design, the Permian water-use assessment is a simplification of a complex and continually developing system and therefore has uncertainty and limitations in the interpretation of results. Despite the modeling limitations, the results summarized in the report, when compared to other studies, compare well with water-use estimations. The favorable comparison highlights the transferability of the water-use methodology to other areas of COG development.

\section{Introduction}

Crude oil and natural gas accumulations are categorized in this report as conventional or continuous (also referred to as "unconventional") based on characteristics of the reservoir (Schmoker, 2005; Schmoker and Klett, 2005). One of the largest conventional oil basins in the United States, the 
Permian Basin, is becoming one of the world's largest continuous oil and gas (COG) resources (Scanlon and others, 2017). Technological advances created mechanisms to extract oil and gas from reservoirs that historically were developed using conventional, or vertical, well drilling techniques (Valder and others, 2018). Continuous well drilling techniques extract oil and gas by horizontally drilling and hydraulically fracturing the reservoir rock surrounding the borehole. Hydraulic fracturing techniques inject water and proppant (usually sand or engineered materials) under pressure into the borehole to generate stress and open fractures in the reservoir rock (Valder and others, 2018). The fractures are held open by the proppant, enabling extraction of reservoir fluids, typically a mix of water, oil, and gas. Extraction of oil and gas from COG reservoirs using hydraulic fracturing requires large volumes of water (Jiang and others, 2014); however, estimating the total volume of water used to extract oil and gas from continuous reservoirs is difficult because geologic properties, drilling depth, and the requirements of hydraulic fracturing vary by well. Water supply challenges for oil and gas extraction in the Permian Basin also result from the semiarid climate, growing population, and limited availability of groundwater and surface-water resources in the basin (Kondash and Vengosh, 2015). Therefore, estimates of water use associated with COG development in the Permian Basin are important in supporting decisions about the use of limited water resources.

In 2015, the U.S. Geological Survey (USGS) started a topical study to quantify water use in areas of COG development. The study was supported through the USGS Water Availability and Use Science Program, which was authorized by the Science and Engineering to Comprehensively Understand and Responsibly Enhance Water Act (SECURE Water Act) in the Omnibus Public Land Management Act of 2009 (16 U.S.C. 1 note). The SECURE Water Act tasked the USGS with completing a national water census to better quantify water use in the United States, including water used to support COG development. Goals of the USGS Water Availability and Use Science Program include the delivery of accurate estimates of water resources in the United States and the development of methods for assessing the quantity and quality of water available for beneficial uses. The topical study to quantify water use related to COG development supports goals of the USGS Water Availability and Use Science Program.

The first phase of the study included the development of a conceptual model (Valder and others, 2018) and analytical framework (Valder and others, 2019) for estimating water use associated with COG development, which were applied in a water-use analysis of the Williston Basin (McShane and others, 2020). The second phase of the study analyzed water use associated with COG development in the Permian Basin using the same approach developed for the Williston Basin. The Permian Basin was selected for the following reasons: (1) the basin has the largest undiscovered and technically recoverable oil and gas resource in the United States, (2) the basin has a continuous resource in tight shale that primarily produces oil, and (3) the basin is within the contiguous United States.

\section{Description of Study Area}

The Permian Basin (fig. 1) is a large carbonate and clastic sedimentary basin that extends across western Texas and southeastern New Mexico, covering more than 75,000 square miles (U.S. Energy Information Administration, 2020c). The basin is asymmetrical and is composed of three main structural subdivisions: the Delaware Basin, Central Basin Platform, and Midland Basin (fig. 1). In addition to these features, the Permian Basin also includes the Val Verde Basin and Ozona Arch in the southeast and is bounded by the Diablo Platform in the west, the Marathon-Ouachita Fold Belt in the south, the Northwest Shelf to the north, and the Eastern Shelf to the east. The generalized stratigraphic sequence of the basin is illustrated in a cross section of the full basin (fig. 2) and as a block schematic of the Midland Basin (fig. 3).

This study used data from 60 counties in Texas and New Mexico within the Permian Basin spatial extent from the U.S. Energy Information Administration (U.S. Energy Information Administration, 2020c), a representation of the geologically defined Permian Basin. Significant accumulations of COG hydrocarbons in the Midland and Delaware Basins of the greater Permian Basin are present in the lower Permian (Leonardian) Spraberry Formation (Midland Basin) and time-equivalent Bone Spring Formation (Delaware Basin), and in the underlying lower Permian to Upper Pennsylvanian (Leonardian to Missourian) Wolfcamp shale (informal name; Gaswirth and others, 2016, 2018) in the Midland and Delaware Basins. Primary sources of sustainable groundwater resources in the Permian Basin include the Pecos Valley aquifer (contained in Quaternary and upper Tertiary alluvium; George and others, 2011), High Plains aquifer (contained in the Neogene Ogallala Formation; locally known in Texas as the Ogallala aquifer; George and others, 2011 and Ryder, 1996), Edwards-Trinity (Plateau) aquifer (contained in the Cretaceous Edwards and Trinity Groups; Barker and Ardis, 1996 and Ryder, 1996), Dockum aquifer (contained in the Triassic Dockum Group; George and others, 2011), Rustler aquifer (contained in the upper Permian [Ochoan] Rustler Formation; George and others, 2011), Capitan Reef Complex aquifer (contained in the middle Permian [Guadalupian] Artesia Group, Goat Seep Dolomite, Capitan Limestone, and equivalent carbonate reef-forming rocks; see George and others [2011] and errata for Standen and others [2009]), and Roswell Basin aquifer system (contained principally in the lower Permian [Leonardian] San Andres Limestone and Glorieta Sandstone; Robson and Banta, 1995; Barroll and Shomaker, 2003). 

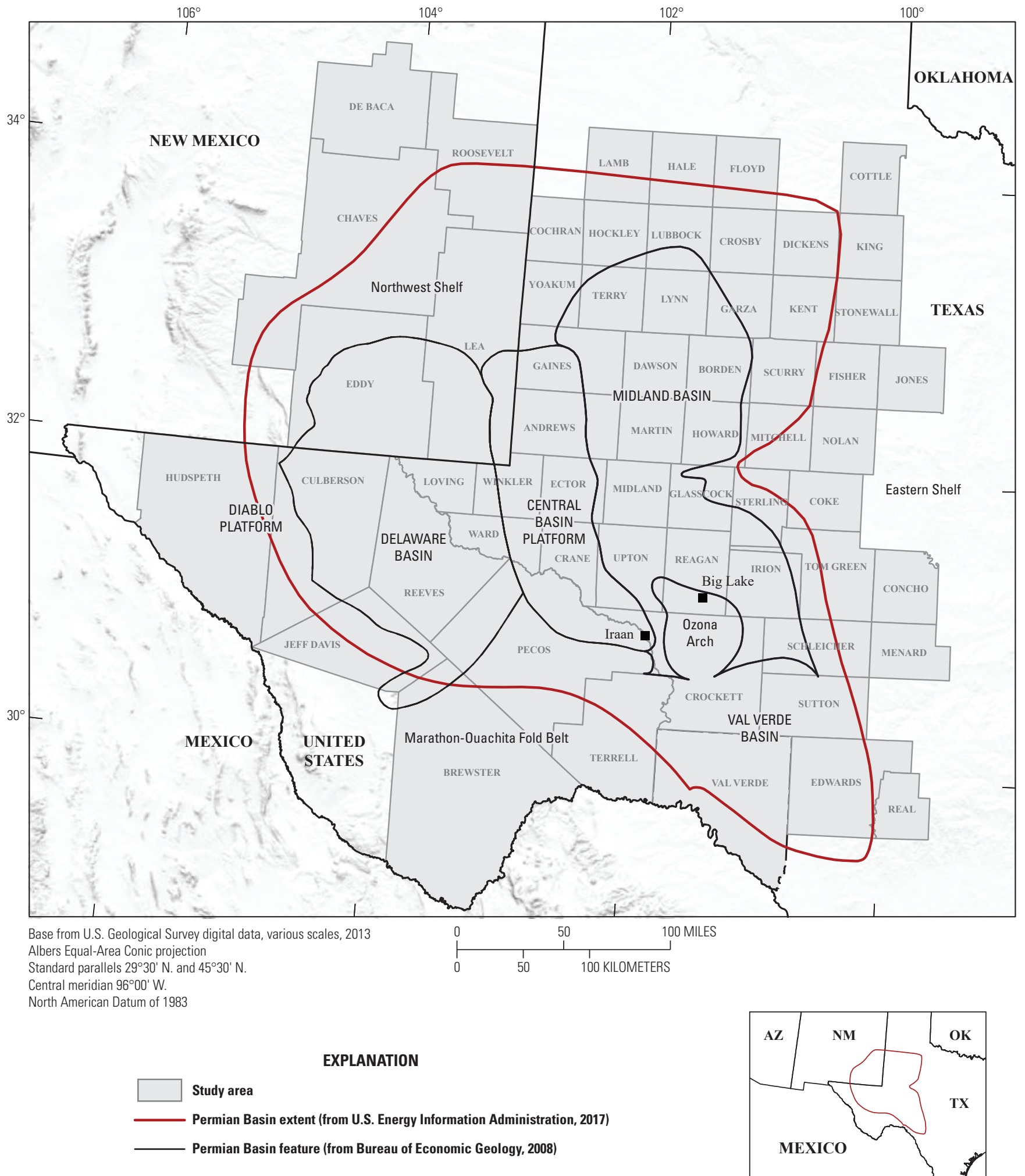

Figure 1. Location of the Permian Basin (U.S. Energy Information Administration, 2017), Permian Basin structural features (Bureau of Economic Geology, 2008), and Texas and New Mexico counties within the study area. 



Figure 2. Generalized geologic cross section characterizing the stratigraphic sequence of the Permian Basin (modified from Matchus and Jones [1984] and Engle and others [2016]).

\section{History of Oil and Gas Development in the Permian Basin}

Since the early 1900s, methods of energy development in the Permian Basin have changed because of many factors including technological developments, production costs, energy prices, and political decisions. The Permian Basin has been an important domestic oil and gas producing region since the 1920s (Dancy, 2018). Other energy resources developed in the Permian Basin include renewable resources, such as wind and solar (U.S. Energy Information Administration, 2020a, b).

Crude oil and natural gas accumulations are categorized as conventional or continuous (also referred to as "unconventional") based on characteristics of the reservoir (Schmoker, 2005; Schmoker and Klett, 2005; fig. 3). Conventional oil and gas accumulations are discrete, with well-defined hydrocarbon-water contacts (where the hydrocarbons are buoyant on a column of water), generally high rock matrix permeabilities, apparent seals and traps, and generally high recovery factors (Schmoker and Klett, 2005). COG accumulations are an oil or gas resource, or both, dispersed evenly throughout a geologic formation rather than existing as discrete and localized deposits like those in conventional accumulations (Schmoker, 2005). These continuous accumulations typically require specialized extraction techniques involving directional, also referred to as "horizontal," wells within this study, which have been more costly than extraction with vertical wells.

The first recorded development in the Permian Basin was an exploratory oil well drilled beginning in the 1880s. In 1903, several more exploratory wells were completed in Reeves County, Texas (fig. 1; Dancy, 2018), to assess the production capacity of the basin. Upper Permian Basin developers drilled vertical wells using cable-tool drilling rigs powered by steam engines. Cable-tool rigs were difficult to work with because the drill bit could bind in the borehole from debris buildup. Despite debris buildup and other technical challenges, early developers preferred the cable-tool rig because the targeted geologic layers were often easier to find using the slower cable drill (Dancy, 2018); however, cable-tool rigs had limited 




Figure 3. Various water and energy features of conventional and continuous oil and gas development in the Midland Basin of the Permian Basin (modified from Carter and others, 2016). The generalized illustration does not show all geologic formations.

capability to control pressure of the formation fluids (water, oil, and gas) while actively drilling. When penetrating the top of an oil or gas reservoir, cable drills often would break through the reservoir unexpectedly, and high fluid pressure in the formation would cause a blowout - an uncontrolled flow of formation fluids out of the top of the well. Early in the development of the Permian Basin, wells were often drilled near railroads to facilitate transport of fuel and water to the well during drilling and transport of oil to refineries after completion. As mud-rotary drilling rigs began to replace cable-tool drilling rigs in the Permian Basin, deeper oil and gas reservoirs were targeted, allowing oil and gas developers to expand their operations as new, and deeper, geologic layers and features became feasible targets.

The first significant commercial oil producing well in the Permian Basin was the Santa Rita 1 well near Big Lake, Tex., in Reagan County (fig. 1), drilled to a depth of 3,050 feet (ft) using the cable-tool drilling method and completed in the Grayburg-San Andres Formation of Guadalupian age (Garber and Harris, 1986; Dancy, 2018). The well took 21 months to drill and was completed on May 27, 1923. The Santa Rita 1 well produced oil for 67 years until it was plugged in 1990 .
A State historical marker, 13.5 miles west of Big Lake, marks the site of the well (American Oil and Gas Historical Society, 2020).

The Big Lake oil field (not shown), where the Santa Rita 1 well was drilled, was the first area of production in the Permian Basin. Although the next eight wells drilled in the Big Lake oil field provided marginal yields, the Santa Rita 9 and 11 wells provided yields that were economically viable (Dancy, 2018). During the same time, well drilling began on the Yates Ranch near Iraan, Tex., in Pecos County (fig. 1). In 1926, Yates well 1-A was drilled to a depth of $997 \mathrm{ft}$ in the San Andres Formation and began producing 3,240 barrels of oil per hour. Development continued on the Yates Ranch, and on September 14, 1929, the Yates well 30-A, drilled to a depth of 1,070 ft, began producing 204,672 barrels of oil per day or about 8,500 barrels of oil per hour (American Oil and Gas Historical Society, 2020). Yates well 30-A was the most productive commercial well drilled before 1929.

The development of the Santa Rita 1 well and then the Yates Ranch wells proved the economic potential of the Permian Basin (Dancy, 2018). After the development of the Yates well 1-A, additional leases on the Yates Ranch were issued to speculators, and the developmental focus turned to 
infrastructure improvements to store and transport the oil. By 1929 , more than 200 wells were producing on the Yates Ranch (Levine and others, 2002). Currently (2021), the Yates Ranch continues to produce oil and gas.

In about 2008, new drilling and extraction techniques, such as horizontal drilling and hydraulic fracturing, became sufficiently developed to allow for production from the lowpermeability and low-porosity formations in the Permian Basin, and the number of wells drilled in the basin started to increase (fig. 4). The development of horizontal drilling, which dates to 1929 but was not in widespread use until the 1980s (Harper, 2008), played a large role in allowing access to the previously unproductive formations present in the Permian Basin, making this one of the most productive basins in the world.

As of September 2018, about 33.4 billion barrels of oil and about 118 trillion cubic feet $\left(\mathrm{ft}^{3}\right)$ of natural gas have been produced from all conventional and continuous wells in the Permian Basin, which accounted for about 35 percent of total U.S. oil production and about 9 percent of total U.S. gas production (U.S. Energy Information Administration, 2020c). Undiscovered, technically recoverable continuous resources in the Wolfcamp shale and Bone Spring Formation are estimated at 46.3 billion barrels of oil and 281 trillion $\mathrm{ft}^{3}$ of gas (Gaswirth and others, 2018). The number of wells producing oil and gas in Texas and New Mexico peaked in the early 1970s, followed by a decrease beginning in the mid-1980s (fig. 4). COG production greatly increased beginning in 2010 with the implementation of hydraulic fracturing and better drilling techniques. As a result, in 2019, crude oil production in Texas exceeded the previous peak of crude oil production in 1972 (U.S. Energy Information Administration, 2020c; fig. 4).

\section{Purpose and Scope}

The purpose of this report is to document direct, indirect, and ancillary estimates of water use associated with COG development in the Permian Basin from 2010 to 2019. Direct water use is defined as water used in a wellbore to complete a well, which includes water used for drilling, cementing, stimulating, and maintaining the well during production. Indirect water use is defined as water used at or near the well site, including water used for dust abatement, equipment cleaning, materials washing, worker sanitation, and site preparation. Ancillary water use is defined as all other water used during the life cycle of COG development that is not categorized as direct or indirect, such as additional local or regional water use resulting from a change (for example, population) related to COG development (McShane and others, 2020). The Permian Basin is the focus of this report because the Permian Basin is one of the primary regions of COG production in the United States (Gaswirth and others, 2016, 2018; Schenk and others,

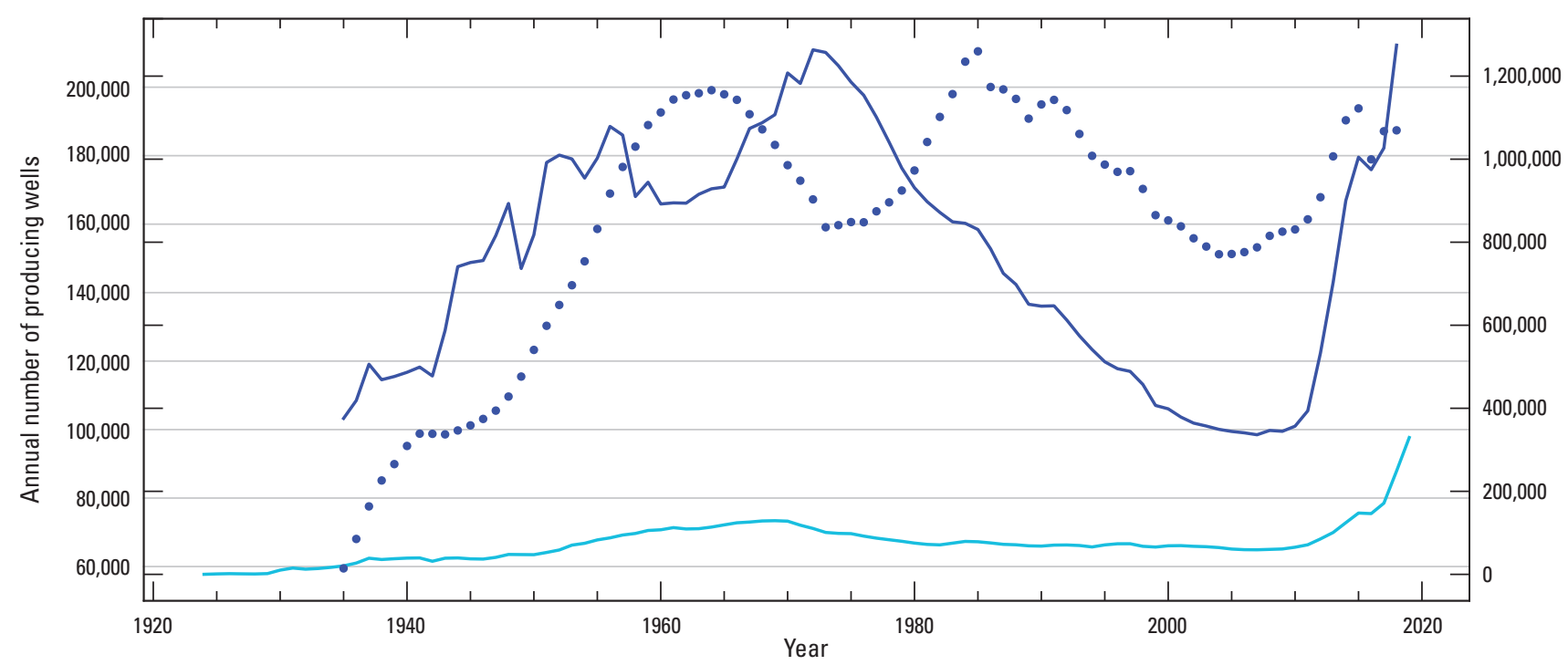

EXPLANATION

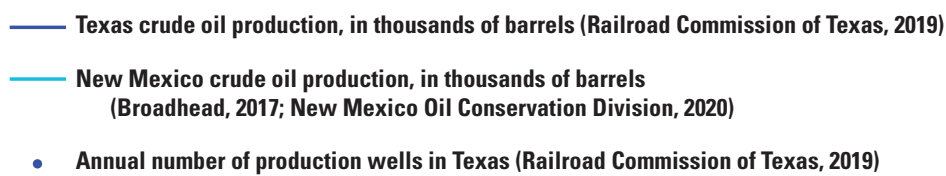

Figure 4. Number of production wells and volume of oil production in the Permian Basin in Texas from 1935 to 2018 (Railroad Commission of Texas, 2019) and volume of oil production in New Mexico from 1923 to 2019 (Broadhead, 2017; New Mexico Oil Conservation Division, 2020). 
2016; Marra and others, 2017). Water use estimated in this report was compared with other published estimates for the Permian Basin.

This report includes three associated USGS data releases. The first data release by Ball and others (2020) includes data used to estimate water use for the Permian Basin. The second data release by McShane and McDowell (2021) includes the following: (1) scripts coded in R (R Core Team, 2020) for executing the procedures used in the water-use analysis and (2) estimates of water use by county and year, and coefficients of water use per developed oil and gas well in the Permian Basin, which can be reproduced using the R scripts. The third data release by Dutton and others (2019) includes data used to estimate water use for the Williston Basin.

\section{Methods for Analyzing Water Use}

The analysis of water use associated with COG development presented in this report was based on the methodology of Valder and others $(2018,2019)$ and McShane and others (2020). Valder and others (2018) developed a conceptual model of water use associated with COG development. The conceptual model consisted of components that represented input data, processes, decisions, model output, and assessment outcomes. Valder and others (2019) established an analytical framework that followed the conceptual model. The analytical framework consisted of a generic approach for estimating direct, indirect, and ancillary water use related to COG development. McShane and others (2020) applied the conceptual model and analytical framework to water use associated with COG development in the Williston Basin in North Dakota and Montana. The data available for the Permian Basin differed from the data available for the Willison Basin; therefore, the analytical framework used for the COG water analysis in the Williston Basin was adapted for use in analyzing water use associated with COG development in the Permian Basin in Texas and New Mexico. However, the methodology used in this study, including data requirements and modeling approach, purposely follows the methodology used in the Williston Basin study to facilitate comparison of results between the two studies and to assess transferability of the methodology from one basin to another.

\section{Procedures for Processing Data for Analysis}

Data from several sources were processed for use in the analysis of direct, indirect, and ancillary water use associated with COG development in the Permian Basin (table 1) and are available in an associated data release (Ball and others, 2020). Data from IHS Markit ${ }^{\mathrm{TM}}$ (2020) were used in the analysis of oil and gas well counts and hydraulic fracturing treatment water (Ball and others, 2020). Data from FracFocus (2020) included hydraulic fracturing treatment water for each well and true vertical depth (not measured depth) for each well. True vertical depth is the vertical distance from the final depth of a well to the land surface, whereas measured depth is the total length of the wellbore, including any curves. Measured depth, because of curves in the wellbore, is necessarily longer than true vertical depth. These data from FracFocus (2020) were used to estimate direct water use in Texas and New Mexico. Data from the Texas Water Development Board (2020) included reported and estimated water use by category, such as industrial or mining, from point and nonpoint sources. These data represented direct and indirect water use, so indirect water use was computed as the difference between data on direct and indirect water use from the Texas Water Development Board (2020) and data on direct water use from FracFocus (2020) and IHS Markit ${ }^{\mathrm{TM}}$ (2020). Because New Mexico lacks water-use data comparable with Texas water-use data, annual values of indirect water use per well in Texas were applied to wells in New Mexico. Estimated water use per county (such as domestic or public supply) from the U.S. Geological Survey (2020) was used with air temperature and precipitation per 4-kilometer grid from the PRISM Climate Group (2020) and the number of people per county from the U.S. Census Bureau (2020) to estimate ancillary water use in Texas and New Mexico (table 1).

Table 1. Information and data sources used to estimate direct, indirect, and ancillary water use associated with continuous oil and gas development in the Permian Basin.

\begin{tabular}{ll}
\hline \multicolumn{1}{c}{ Data source } & \multicolumn{1}{c}{ Information } \\
\hline IHS Markit & $\begin{array}{c}\text { Hydraulic fracturing treatment water use per square mile. } \\
\text { Oil and gas well count per square mile. }\end{array}$ \\
$\begin{array}{l}\text { FracFocus (2020) } \\
\text { Texas Water Development Board (2020) }\end{array}$ & Wydraulic fracturing treatment water use per oil and gas well. \\
$\begin{array}{l}\text { PRISM Climate Group (2020) } \\
\text { U.S. Census Bureau (2020) }\end{array}$ & Air temperature and precipitation per 4-kilometer grid. \\
$\begin{array}{l}\text { U.S. Geological Survey (Kenny and others, 2009; } \\
\text { Maupin and others, 2014; Dieter and others, 2018) }\end{array}$ & Number of people per county. \\
\hline
\end{tabular}


Data processing for the Permian Basin study generally followed the procedures used in the Williston Basin study (McShane and others, 2020); however, the main difference between the two studies was that data were processed separately for North Dakota and Montana in the Williston Basin, whereas data for Texas and New Mexico were combined for the Permian Basin. The reason for the difference was that some data sources were specific to each State in the Williston Basin, but most data for the Permian Basin were from the same source for both States.

Like the Williston Basin study (McShane and others, 2020), hydraulic fracturing treatment water data were used to determine when oil and gas production related to COG development in the Permian Basin began to increase (fig. 4). Water-use data for hydraulic fracturing treatment (table 1) were summed by year, and a segmented linear regression model of the relation between hydraulic fracturing treatment water and year of observation was developed using the "segmented" package in R (Muggeo, 2018). The segmented linear regression was used to determine the year that the rate of water use per year changed. The year of this change is known as a breakpoint, and the breakpoint was used to separate the water-use data into observations that preceded the increase in COG development and those that followed the increase. The observations before the breakpoint were used to model baseline water use before the increase in COG development. The breakpoint used in the water-use analysis was 2010 . The data from 2010 (the breakpoint year) to 2019 were used for estimating direct, indirect, and ancillary water use.

Water-use data were aggregated by county and year, which were designated as the sampling units used in this analysis. There were 60 counties in Texas and New Mexico with data on water use associated with COG development in at least 1 of the 10 years (2010-19) of data used in the water-use analysis. The result was 471 sampling units (county and year) for analysis.

Water use for drilling and cementing was estimated from available data on true vertical depth for each well (FracFocus, 2020; table 1). Data on lengths or diameters of casings cemented or of boreholes drilled were not available, so several simplifying assumptions were required. Water use for drilling was assumed to be a mean ratio of water volume to borehole volume of about 2 , and wellbores were assumed to be a mean of about $1 \mathrm{ft}^{3}$ of volume per $1 \mathrm{ft}$ of depth. Therefore, to estimate water use for drilling, vertical well depth was multiplied by 15 gallons of water (about $2 \mathrm{ft}^{3}$ of water), which is the volume of water that is about twice the mean per-foot borehole volume. Water use for cementing was assumed to be a mean ratio of water weight to cement weight of about 0.5 , which followed McShane and others (2020), and casing annular volumes were assumed to be a mean of about one-quarter of the borehole volume. Therefore, to estimate water use for cementing, vertical well depth was multiplied by 1.5 gallons of water, which is the volume of water with a weight (about 12 pounds) that is about one-half of the weight of $0.25 \mathrm{ft}^{3}$ of dry portland cement (about 25 pounds).
Indirect water use was estimated from water-use data for point and nonpoint sources (Texas Water Development Board, 2020; table 1). Water use was reported by year for various categories, such as industrial or mining, consistent with the water-use categories used for the USGS National Water Census (U.S. Geological Survey, 2020). The reported water use was summed by county and year and was assumed to represent the total water use at oil and gas well sites in a given county and year. Direct water use in a given county and year was subtracted from total water use related to COG development, and the remainder was assumed to represent indirect water use. In this report, direct and indirect water use together are referred to as "COG mining water use."

Annual ancillary water-use data were not available for Texas or New Mexico; therefore, water-use data from the USGS National Water Census were used (U.S. Geological Survey, 2020). These data are compiled every 5 years for water-use categories such as domestic, public supply, industrial, mining, and thermoelectric power (table 1). Annual values were estimated by linear interpolation between every fifth year. Ancillary water use is represented as parts of other nonmining water-use categories. It was assumed that the domestic and public-supply water-use categories were most directly affected by COG development because of attendant population growth, and these categories are referred to as "populationbased ancillary water use" in this report. Additionally, it was assumed that industrial, mining other than COG (referred to as "non-COG mining" in this report), and thermoelectric power water use might be indirectly affected by COG development because of potential accompanying economic growth, and these categories are referred to as "other potential ancillary water use" in this report.

Like the Williston Basin study (McShane and others, 2020), the breakpoint analysis was used to account for preexisting trends in the ancillary water-use categories (domestic, public supply, industrial, non-COG mining, and thermoelectric power) before the rise in COG development. A linear regression model was developed between water use for these categories and a combination of county, annual total precipitation per county, annual mean temperature per county, and population per county for the years before the breakpoint (2010). The antecedent trend in water use, determined from the linear regression, was extrapolated forward into the years after the breakpoint to estimate 2010-19 water use. The estimates of 2010-19 water use were subtracted from the USGS wateruse data, which removed the effect of population and climate on the ancillary water-use categories before the increase in COG development. The remaining water use was attributed to COG development based on the assumption that no factors other than COG development affected the ancillary water-use categories. 


\section{Procedures for Modeling Water Use and Uncertainty}

The procedures used for modeling water use and uncertainty in this study followed the procedures used in the Williston Basin study (McShane and others, 2020). The main difference between the Williston Basin and Permian Basin studies is that water use in the Williston Basin was estimated for the direct, indirect, and ancillary categories only for all years together, whereas water use in the Permian Basin was estimated not only for all years together but also for each year separately. The reason for this difference was that after publishing the water-use analysis of the Williston Basin (McShane and others, 2020), a subsequent reanalysis of the data indicated that water-use estimates for each year separately provided more information than water-use estimates for all years together. Therefore, data for the Williston Basin study (Dutton and others, 2019) were reanalyzed on an annual basis for comparison with the annual analysis for the Permian Basin.

Linear and quantile regression models of water use in relation to the number of oil and gas wells developed were fit for the direct, indirect, and ancillary water-use categories for the Permian Basin to estimate water use associated with COG development. A 95-percent confidence interval for each parameter estimate (coefficient) from the linear regression models was computed as a measure of uncertainty. Additionally, quantile regression models of the 5th, 50th (median), and 95th percentiles also were fit using the "quantreg" package in R (Koenker, 2018). Coefficients of water use from the linear and quantile regression models are in million gallons per well because volume of water use was regressed on number of wells per sampling unit (county and year). Estimates of water use, in million gallons per year per sampling unit, were computed by multiplying the water-use coefficients by the number of wells per county and year, consistent with water-use data from the USGS National Water Census (U.S. Geological Survey, 2020).

Uncertainty in the estimates from the regression models of direct, indirect, and ancillary water use was assessed using leave-one-out cross validation (Hastie and others, 2009). Leave-one-out cross validation is an iterative process that leaves out a sampling unit, fits a model to all remaining sampling units, uses the fitted model to predict the value for the left-out sampling unit, and then repeats for each sampling unit. The process was applied to all 471 sampling units in the Permian Basin, and the 471 estimates were validated with the 471 observations of water use.

Performance of the regression models was evaluated with three goodness-of-fit metrics used to evaluate water-use estimates with observations. The first metric was the coefficient of determination $\left(R^{2}\right)$, which is the square of the Pearson productmoment correlation coefficient (Legates and McCabe, 1999). An $R^{2}$ value greater than 0.5 may be considered acceptable. In this study, relating water use to the number of developed oil and gas wells disregarded potentially informative spatial and temporal variability in the data, so an $R^{2}$ value greater than 0.5 could be difficult to attain with the regression models.

The second metric was root mean square error (RMSE), which is the square root of the mean square error of the regression model (Legates and McCabe, 1999), or the standard deviation of the residuals (unexplained variance) of the regression model (Moriasi and others, 2007). An acceptable value for RMSE was difficult to determine because the values are specific to the data; therefore, RMSE was used in relation to the parameter estimate from the regression model as a measure of goodness of fit; for example, an RMSE value less than 25 percent of one parameter estimate is better than an RMSE value greater than 50 percent of another parameter estimate.

The third metric was the ratio of the RMSE relative to the standard deviation of the observations (RSR), which is the relation of the standard deviation of the unexplained variance in the regression model to the standard deviation of the observations (Moriasi and others, 2007). An RSR value less than 0.5 is considered acceptable (Moriasi and others, 2007).

Human population change in the Permian Basin was modeled to support the analysis of ancillary water use for domestic and public supply. Population growth was assumed to correlate with COG development. The population of all 60 Texas and New Mexico counties in the Permian Basin together was estimated with a linear regression model relating the number of people to the number of oil and gas wells developed in the same year and in the 1-5 years before the year. The additional years were used to compensate for a lagged response of population growth to COG development. A relation between the number of people and number of wells with an $R^{2}$ value of 0.5 or more was assumed to indicate that water use for domestic and public supply could be attributed to $\mathrm{COG}$ development.

\section{Results of Water-Use Analysis}

Water-use analysis of the Permian Basin contained three elements: (1) estimates of water use associated with COG development, in million gallons per year, by county and year (from 2010 to 2019); (2) coefficients of water use from the regression models, in million gallons per developed oil and gas well; and (3) performance (based on goodness-of-fit metrics) of the regression models in estimating (predicting) the observed water use. In this report, ancillary water use refers only to the domestic and public-supply (population-based) water-use categories.

\section{Estimates of Water Use by County and Year}

Estimates from the linear and quantile regression models of direct, indirect, and ancillary water use in the Permian Basin were summed across all counties and the mean determined over all years in the analysis (table 2). Mean annual 
Table 2. Mean annual estimates from linear and quantile regression models of direct and indirect, ancillary, and other potential ancillary water use associated with continuous oil and gas development in the Permian Basin (2010-19).

[Values are in million gallons per year. $\mathrm{COG}$, continuous oil and gas]

\begin{tabular}{|c|c|c|c|c|c|c|}
\hline \multirow{2}{*}{ Use } & \multirow{2}{*}{ Mean } & \multicolumn{2}{|c|}{ 95-percent confidence interval limits } & \multicolumn{3}{|c|}{ Percentiles } \\
\hline & & Lower & Upper & 5th & 50th & 95th \\
\hline \multicolumn{7}{|c|}{ Direct and indirect water use } \\
\hline All direct ${ }^{\mathrm{a}}$ & 33,058 & 32,583 & 33,549 & 6,651 & 20,142 & 80,770 \\
\hline Direct-hydraulic fracturing & 32,164 & 31,284 & 33,102 & 5,815 & 19,286 & 79,865 \\
\hline Direct—cementing & 81.3 & 75.4 & 88.3 & 64.9 & 81.4 & 98.8 \\
\hline Direct—drilling & 813 & 754 & 883 & 649 & 814 & 988 \\
\hline Indirect & 719 & 675 & 770 & 392 & 620 & 1,230 \\
\hline Direct and indirect $-\mathrm{COG}$ mining ${ }^{\mathrm{b}}$ & 33,777 & 33,258 & 34,319 & 7,043 & 20,762 & 82,000 \\
\hline \multicolumn{7}{|c|}{ Ancillary (population-based) water use } \\
\hline All ancillaryc & 7,386 & 4,734 & 10,038 & 4,686 & 7,210 & 10,582 \\
\hline Ancillary-domestic & 453 & 114 & 885 & 244 & 341 & 1,128 \\
\hline Ancillary_public supply & 6,933 & 4,750 & 9,116 & 4,870 & 6,553 & 9,253 \\
\hline \multicolumn{7}{|c|}{ Other potential ancillary water use } \\
\hline Industrial & 882 & 549 & 1,216 & 681 & 909 & 1,118 \\
\hline Non-COG mining & 53,730 & 34,785 & 72,676 & 33,152 & 52,625 & 81,183 \\
\hline Thermoelectric power & 3,535 & 2,247 & 4,824 & 3,219 & 3,605 & 3,843 \\
\hline
\end{tabular}

aAll direct water use was modeled independently, so the values are not the sum of the hydraulic fracturing, cementing, and drilling values.

birect and indirect water use was modeled independently, so the values are not the sum of all direct and indirect values.

${ }^{c}$ All ancillary water use was modeled independently, so the values are not the sum of the domestic and public-supply values. 
direct and indirect water use for COG development in the Permian Basin was estimated at 33,777 million gallons per year (Mgal/yr), with a 95 -percent confidence interval of 33,258-34,319 Mgal/yr (table 2). Hydraulic fracturing accounted for 95 percent of direct and indirect water use. All ancillary water use had a mean annual estimate of $7,386 \mathrm{Mgal} / \mathrm{yr}$ in the Permian Basin. Other ancillary water use included mean annual estimates of $882 \mathrm{Mgal} / \mathrm{yr}$ for industrial, $53,730 \mathrm{Mgal} / \mathrm{yr}$ for non-COG mining, and 3,535 Mgal/yr for thermoelectric power.

Direct and indirect water-use estimates in Texas and New Mexico varied by year (fig. $5 A, B$ ). Direct water use trended upward and in 2019 reached 72,220 Mgal/yr in Texas (fig. 5A). New Mexico had a similar trend and reached 11,403 Mgal/yr in 2019 (fig. $5 B$ ) - a value 6.3 times less in New Mexico than in Texas. Mean annual direct water use, computed using data for all years in Texas (fig. $5 A$ ) or New Mexico (fig. $5 B$ ), was 28,732 Mgal/yr in Texas and 4,326 Mgal/yr in New Mexico. Direct water use steadily increased in Texas and New Mexico from 2010 and nearly tripled between 2016 and 2019 (fig. 5A, $B)$. The temporal variability in direct water use indicates differences in the number of oil and gas wells developed per year and the volume of water used per well. Mean annual indirect water use, which was computed using data for all years in Texas (fig. $5 A$ ) or New Mexico (fig. $5 B$ ), was $605 \mathrm{Mgal} / \mathrm{yr}$ in Texas and $114 \mathrm{Mgal} / \mathrm{yr}$ in New Mexico. Indirect water use varied less temporally than did direct water use (fig. $5 A, B$ ). The standard deviation relative to the mean (coefficient of variation; computed using data for all years in Texas or New Mexico) for direct and indirect water use was 0.9 and 0.4 , respectively, in Texas and 0.9 and 0.6 , respectively, in New Mexico. These differences in the coefficient of variation indicated less temporal variation in indirect water use than in direct water use in both States. Additionally, the mean ratio of direct to indirect water use, computed using data for all years in Texas or New Mexico, was greater in Texas (48) than in New Mexico (38), which can be attributed to a greater upward trend in hydraulic fracturing water use in Texas (fig. $5 A$ ) than in New Mexico (fig. 5B).

Ancillary water-use estimates also varied by year (fig. 5A, B). In Texas, ancillary water use was highest in 2011 $(6,142 \mathrm{Mgal} / \mathrm{yr}$; fig. $5 A)$, but in New Mexico, the peak was in 2014 (3,488 Mgal/yr; fig. 5B). The ratio of direct and indirect water use to ancillary water use, computed using data for all years in Texas or New Mexico, was 6 in Texas and 2 in New Mexico. Mean annual ancillary water use from 2010 to 2019, which was computed using data for all years in Texas or New Mexico, was 5,068 Mgal/yr in Texas and 2,318 Mgal/yr in New Mexico. Ancillary water use did not have an upward trend like direct water use (fig. $5 A, B$ ).

Mean annual direct and indirect water-use estimates in Texas and New Mexico varied by county (fig. 6A, B). Direct water use was greatest in Loving, Glasscock, Howard, Upton, Reagan, Martin, Reeves, and Midland Counties in Texas, ranging from 1,853 to 4,646 Mgal/yr (fig. 6A). In New Mexico, direct water use was greatest in Lea (2,218 Mgal/yr) and Eddy
(2,088 Mgal/yr) Counties (fig. 6B). These 10 counties in Texas and New Mexico had more than 1,000 Mgal/yr of direct water use. In New Mexico, only one other county (Chaves County) had more than $10 \mathrm{Mgal} / \mathrm{yr}$ of direct water use. In Texas, 9 additional counties had more than $100 \mathrm{Mgal} / \mathrm{yr}$ of direct water use, and another 10 counties had at least $10 \mathrm{Mgal} / \mathrm{yr}$. The county with the most direct water use in Texas (Midland County) used 2.1 times more than the county with the most direct water use in New Mexico (Lea County). Spatial variation in direct water use indicates differences in the number of oil and gas wells developed per county and the volume of water used per well among counties. In Texas, the counties with the most indirect water use-Ector, Andrews, Loving, Glasscock, Howard, Upton, Reagan, Martin, Reeves, and Midland Counties - ranged from 29 to $67.8 \mathrm{Mgal} / \mathrm{yr}$ (fig. 6A). In New Mexico, Eddy (63.6 Mgal/yr) and Lea (48.9 Mgal/ yr) Counties had the most indirect water use (fig. $6 B$ ). Spatial variation in indirect water was less than in direct water use in Texas but not in New Mexico. The coefficients of variation for direct and indirect water use were 2 and 1.6, respectively, in Texas, which indicates less spatial variation in indirect water use than in direct water use for hydraulic fracturing; however, in New Mexico, the coefficient of variation was the same (1.4) for direct and indirect water use. Comparisons between the coefficients of variation by county and coefficients of variation by year indicate that indirect and direct water use vary less temporally than spatially.

Ancillary water-use estimates also varied by county in Texas and New Mexico (fig. 6A, $B$ ) and were dispersed unevenly among the counties in each State. In the Permian Basin, 35 of 60 counties had ancillary water use that exceeded direct and indirect water use- 3 of 5 counties in New Mexico and 32 of 55 counties in Texas. In New Mexico, 3 countiesEddy, Lea, and Chaves Counties - had more than 90 percent of ancillary water use. In Texas, no county had more than 10 percent of ancillary water use, and 26 counties had at least 1 percent of ancillary water use. The difference between the States indicates that ancillary water use in Texas was more varied spatially than in New Mexico. In addition, Midland County in Texas and Lea County in New Mexico (the counties with the most direct water use in their respective State) had ancillary water use that was 2 and 29 percent of their respective direct water use.

A comparison of ancillary water use to direct water use indicated that ancillary water use did not vary as a function of direct water use - from 2010 to 2019, ancillary water use remained relatively constant compared to direct water use, which steadily increased. However, the comparison of annual population in the Permian Basin to number of oil and gas wells developed indicated that time-lagged (5 years) population increased as a function of direct water use. In the 55 Texas counties and 5 New Mexico counties in the study area with at least 1 developed oil and gas well, population increased from 1.31 million in 2010 to 1.43 million in 2019 (fig. 7; U.S. Census Bureau, 2020). This trend in population growth was best explained with a linear regression model of 

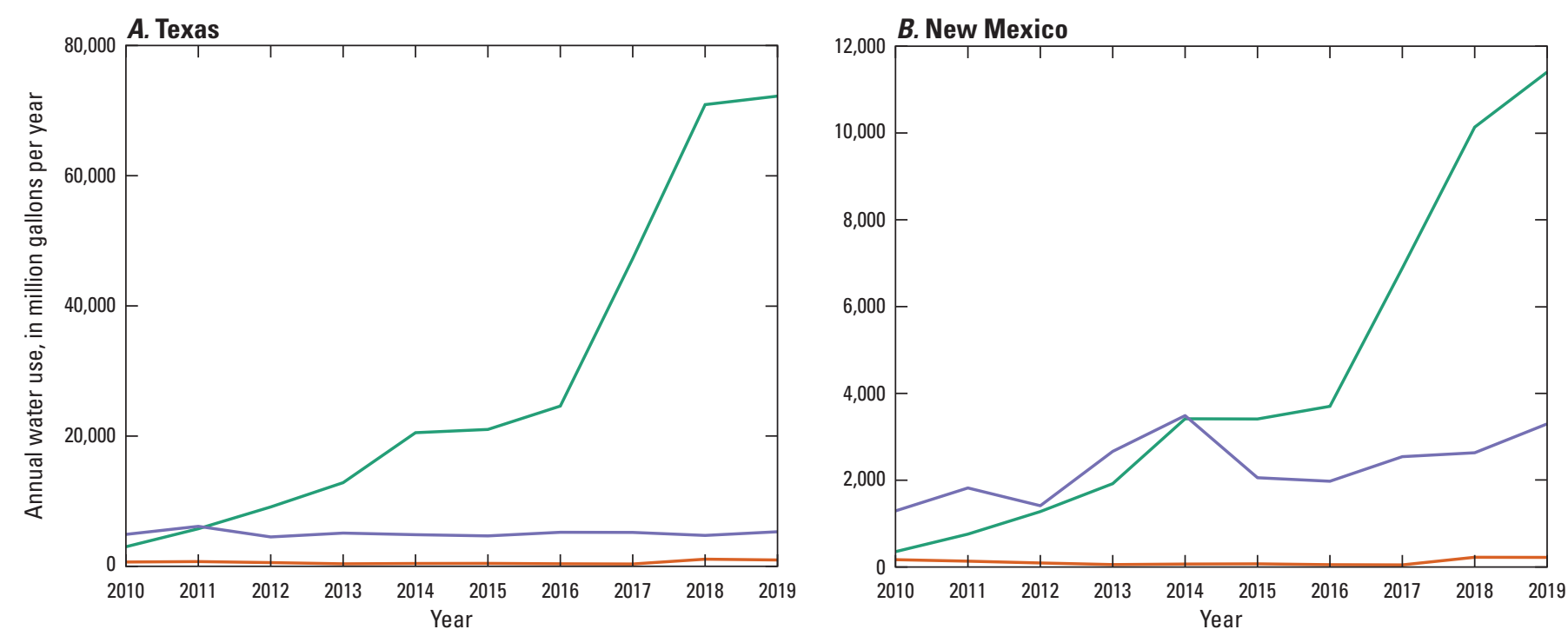

EXPLANATION

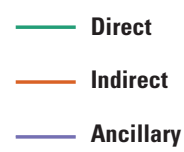

Figure 5. Annual estimates from linear regression models of direct, indirect, and ancillary water use in the Permian Basin from 2010 to 2019 in $(A)$ Texas and $(B)$ New Mexico.
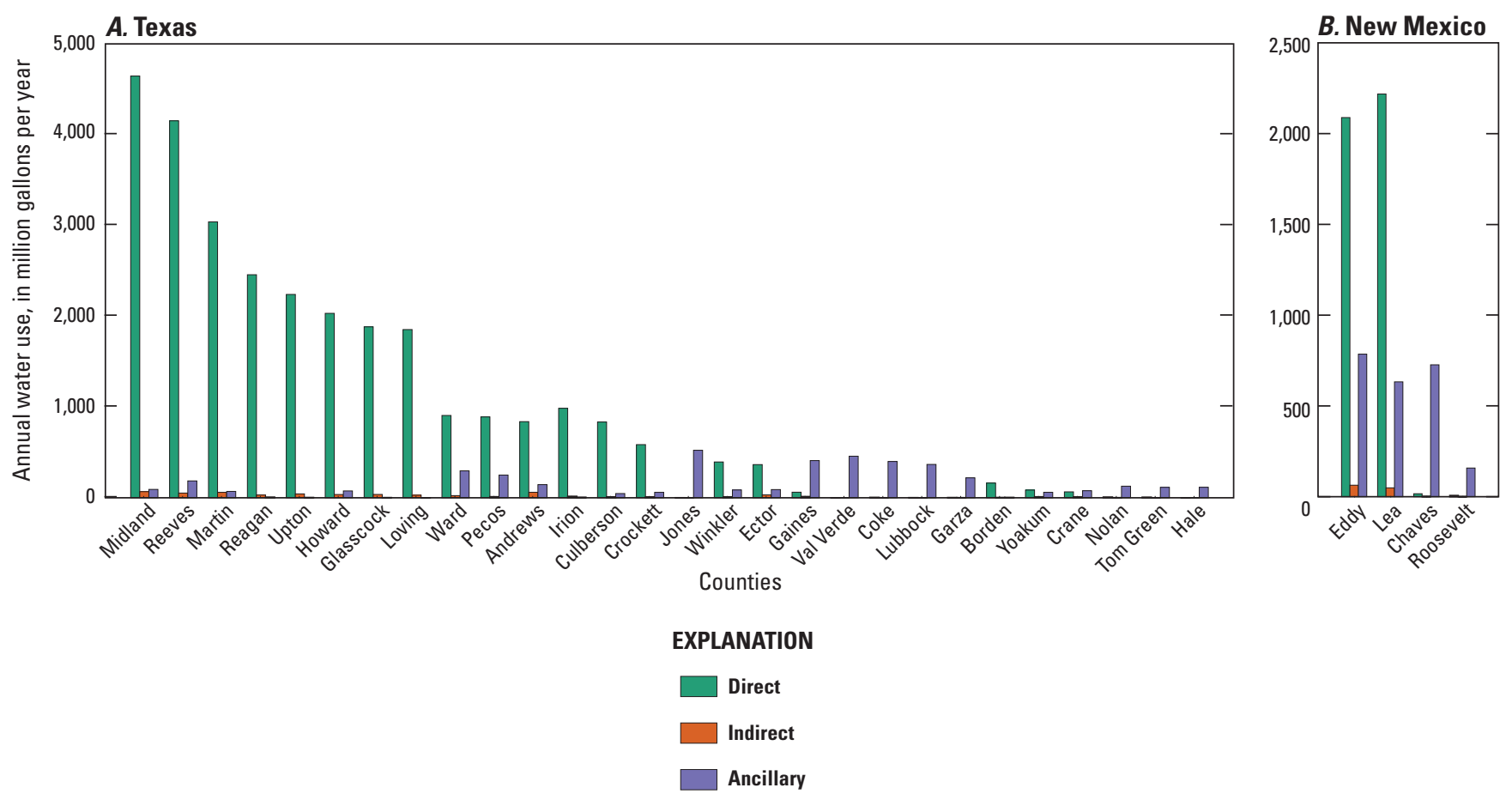

Figure 6. Mean annual estimates from linear regression models of direct, indirect, and ancillary water use by county in the Permian Basin from 2010 to 2019 in $(A)$ Texas and $(B)$ New Mexico. 


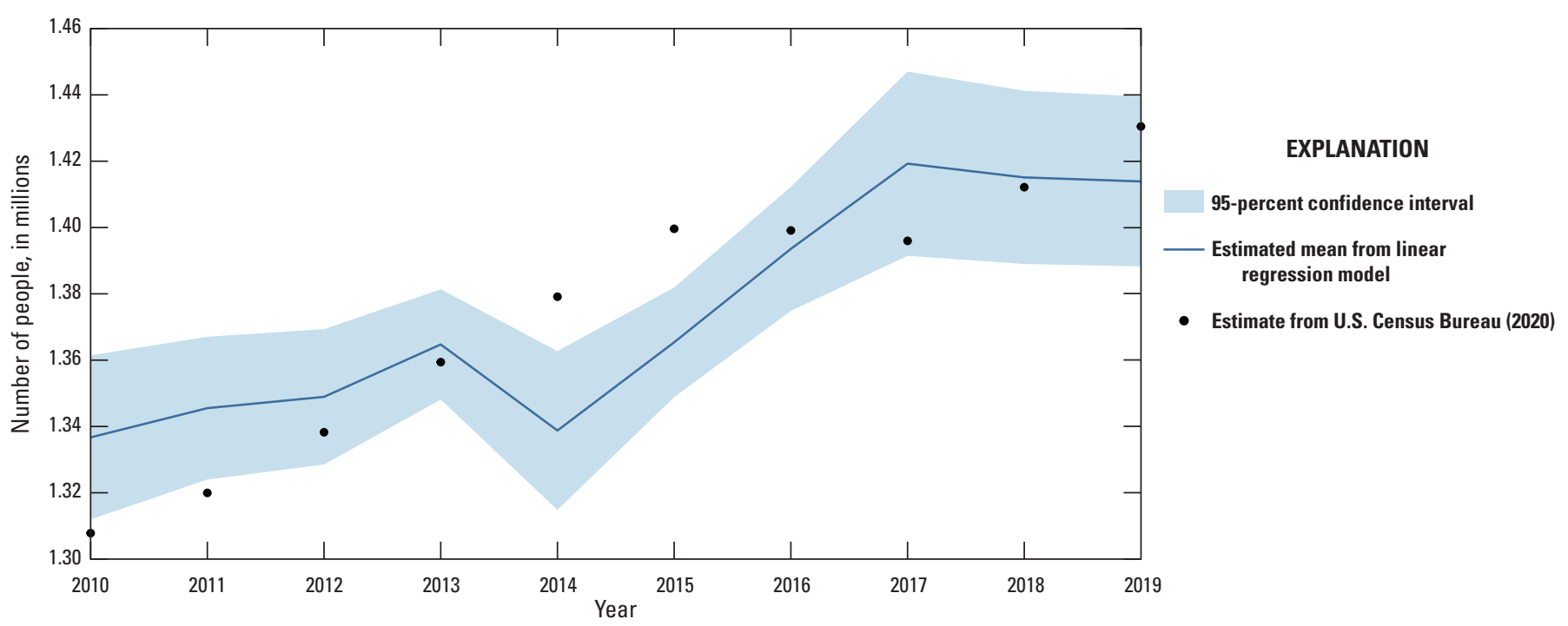

Figure 7. Linear regression model of population as explained by number of oil and gas wells developed per year in the Permian Basin (2010-19).

the relation between the annual population and the number of oil and gas wells developed 5 years previously (a 5-year lag). The number of wells developed in the Permian Basin increased from about 5,000 in 2010, peaked at about 8,000 between 2012 and 2014, and then declined to about 5,000 in 2019 (McShane and McDowell, 2021). The mean estimate from the linear regression model $\left(R^{2}=0.65\right)$ was 15 people added per developed oil and gas well; however, the correlation between increase in population and increase in number of wells developed may not be causal. The Permian Basin has been developed for more than 100 years, and changes in population may be affected by other circumstances unrelated to oil and gas development.

Estimates of water use by county and year used for Texas and New Mexico are available in an associated data release (McShane and McDowell, 2021). The estimates include direct and indirect water use and ancillary water use for the domestic, public-supply, industrial, non-COG mining, and thermoelectric power categories. Ancillary water use for the domestic and public-supply categories (population based) is directly related to $\mathrm{COG}$ development, but the other potential ancillary water-use categories (industrial, non-COG mining, or thermoelectric power) are indirectly associated with $\mathrm{COG}$ development. The values for the ancillary water-use categories (McShane and McDowell, 2021) represent the part of those categories attributable to COG development as determined by the water-use analysis of the Permian Basin.

\section{Coefficients of Water Use per Developed Oil and Gas Well}

Coefficients from the linear and quantile regression models of direct, indirect, and ancillary water use in the Permian Basin were produced as aggregate values for all the counties and years (table 3). Additionally, estimates for annual mean direct, indirect, and ancillary water use were generated.

The coefficient (mean estimate) from the linear regression model was 4.79 million gallons (Mgal) per well for all direct water use and $4.63 \mathrm{Mgal}$ per well for hydraulic fracturing water use (table 3). The mean estimate of cementing and drilling water use was 0.014 and $0.143 \mathrm{Mgal}$ per well, respectively. Water use for cementing and drilling was 3.3 percent of the mean estimate of hydraulic fracturing water use. The mean estimate of all direct water use had a 95-percent confidence interval of 4.13-5.45 Mgal per well. From the quantile regression model, the 5th, 50th, and 95th percentile estimates of all direct water use were $0.548,1.98$, and $18.0 \mathrm{Mgal}$ per well, respectively (table 3). Hydraulic fracturing water use at the lower and higher percentile estimates were outside the confidence interval for the mean estimate, indicating that direct water use, which mostly consists of hydraulic fracturing water use, in the Permian Basin is highly variable in space or time, or both.

The coefficient from the linear regression model of indirect water use was $0.111 \mathrm{Mgal}$ per well, with a 95-percent confidence interval of 0.104-0.117 Mgal per well (table 3). The 5th, 50th, and 95th percentile estimates from the quantile regression model were $0.053,0.108$, and 0.223 Mgal per well, respectively.

Direct and indirect (COG mining) water use had a mean estimate of 4.90 Mgal per well in the Permian Basin (table 3). The 5 th percentile estimate of COG mining water use was 
Table 3. Coefficients from linear and quantile regression models of direct and indirect, ancillary, and other potential ancillary water use per oil and gas well developed in the Permian Basin (2010-19).

[Values are in million gallons per well. COG, continuous oil and gas]

\begin{tabular}{|c|c|c|c|c|c|c|}
\hline \multirow{2}{*}{ Use } & \multirow{2}{*}{ Mean } & \multicolumn{2}{|c|}{ 95-percent confidence interval limits } & \multicolumn{3}{|c|}{ Percentiles } \\
\hline & & Lower & Upper & 5th & 50th & 95th \\
\hline \multicolumn{7}{|c|}{ Direct and indirect water use } \\
\hline All direct ${ }^{\mathrm{a}}$ & 4.79 & 4.13 & 5.45 & 0.548 & 1.98 & 18.0 \\
\hline Direct_-hydraulic fracturing & 4.63 & 3.97 & 5.29 & 0.349 & 1.81 & 17.9 \\
\hline Direct - cementing & 0.014 & 0.014 & 0.015 & 0.01 & 0.014 & 0.017 \\
\hline Direct—drilling & 0.143 & 0.14 & 0.146 & 0.1 & 0.139 & 0.172 \\
\hline Indirect & 0.111 & 0.104 & 0.117 & 0.053 & 0.108 & 0.223 \\
\hline Direct and indirect $-\mathrm{COG}$ mining ${ }^{\mathrm{b}}$ & 4.90 & 4.23 & 5.56 & 0.601 & 2.09 & 18.3 \\
\hline \multicolumn{7}{|c|}{ Ancillary (population-based) water use } \\
\hline All ancillaryc & 1.09 & 1.05 & 1.13 & 0.688 & 1.16 & 1.73 \\
\hline Ancillary-domestic & 0.071 & 0.064 & 0.078 & 0.035 & 0.05 & 0.308 \\
\hline Ancillary_public supply & 1.02 & 0.983 & 1.06 & 0.63 & 1.03 & 1.68 \\
\hline \multicolumn{7}{|c|}{ Other potential ancillary water use } \\
\hline Industrial & 0.128 & 0.123 & 0.133 & 0.093 & 0.122 & 0.214 \\
\hline Non-COG mining & 7.39 & 6.90 & 7.88 & 3.82 & 6.77 & 18.5 \\
\hline Thermoelectric power & 0.527 & 0.511 & 0.544 & 0.418 & 0.506 & 0.784 \\
\hline
\end{tabular}

aAll direct water use was modeled independently, so the values are not the sum of the hydraulic fracturing, cementing, and drilling values.

${ }^{b}$ Direct and indirect water use was modeled independently, so the values are not the sum of all direct and indirect values.

cAll ancillary water use was modeled independently, so the values are not the sum of the domestic and public-supply values. 
$0.601 \mathrm{Mgal}$ per well, or 12 percent of the mean estimate, and the 95th percentile estimate was $18.3 \mathrm{Mgal}$ per well, or 3.7 times greater than the mean estimate. The mean estimate of COG mining water use was greater than the mean estimate of direct water use by 2 percent, meaning that estimates of all direct water use alone might underestimate water use for $\mathrm{COG}$ development in the Permian Basin. The COG mining wateruse estimate included not only water used for completing a well (direct water use) but also other water used at the well site (indirect water use).

The mean estimate of all ancillary water use in the Permian Basin was 1.09 Mgal per well, with a 95-percent confidence interval of 1.05-1.13 Mgal per well (table 3). Publicsupply water use was 14 times greater than domestic water use. Other potential ancillary water use included $0.128,7.39$, and $0.527 \mathrm{Mgal}$ per well (mean estimates; table 3) for industrial use, non-COG mining use, and thermoelectric power use, respectively. The 5th, 50th, and 95th percentile estimates for other potential ancillary water use ranged from 0.093 Mgal per well for industrial to $18.5 \mathrm{Mgal}$ per well for non-COG mining.
The linear regression models also were used to generate annual mean estimates of hydraulic fracturing, cementing, drilling, indirect, and ancillary water use (fig. $8 A, B$ ). Hydraulic fracturing water use had a mean estimate of $0.587 \mathrm{Mgal}$ per well in 2010 and 16.9 Mgal per well in 2019, 29 times greater in 2019 than in 2010 (fig. 8A). Annual coefficients for cementing and drilling water use per well varied negligibly, with maximum values greater than minimum values by 23 percent (fig. $8 B$ ); however, maximum values of annual coefficients for indirect water use and ancillary water use were 4.2 and 3.4 times greater than minimum values, respectively (fig. $8 B$ ).

Coefficients of water use are available in an associated data release (McShane and McDowell, 2021). The coefficients include direct and indirect water use and ancillary water use for the domestic, public-supply, industrial, non-COG mining, and thermoelectric power categories. The values for the ancillary water-use categories (McShane and McDowell, 2021) represent the part of those categories attributable to COG development as determined by the water-use analysis of the Permian Basin.

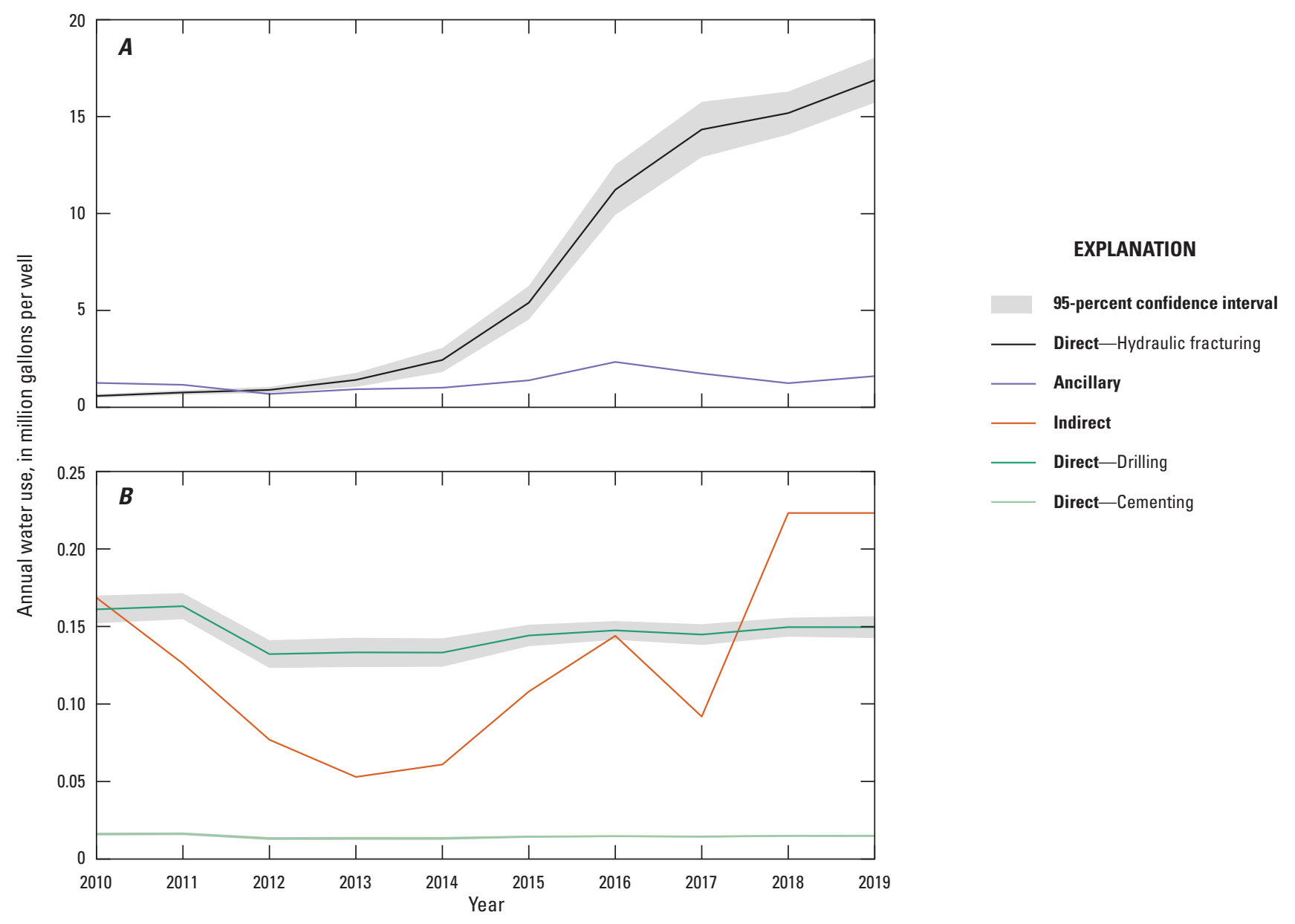

Figure 8. Annual estimates of direct, indirect, and ancillary water use in the Permian Basin from 2010 to 2019 for $(A)$ hydraulic fracturing (direct) and ancillary uses and $(B)$ indirect, drilling (direct), and cementing (direct) uses. 


\section{Performance of Regression Models of Water Use}

Model performance was evaluated with goodness-of-fit metrics ( $R^{2}, \mathrm{RMSE}$, and RSR) computed from leave-one-out cross validation of the linear and quantile regression models of direct, indirect, and ancillary water use (table 4). The two dimensionless metrics ( $R^{2}$ and RSR) differed marginally among water-use categories, but RMSE varied by a factor of about 100 .

Performance of the linear regression model for all direct water use was acceptable (table 4), with an $R^{2}$ value of 0.91 . Fit of the linear regression model of all direct water use to number of oil and gas wells developed also was acceptable (fig. 9A), and the dispersion in differences between estimated and observed values of water use did not trend toward underor overprediction (fig. 10A). Values of RMSE for the direct water-use categories ranged from 0.007 Mgal per well for cementing water use to $2.50 \mathrm{Mgal}$ per well for all direct water use, ranging from 50 to 52 percent of their respective mean coefficients (table 3). Values of RSR for the direct water-use categories ranged from 0.19 to 0.29 , meaning that the standard deviation of the residuals from a linear regression model of a water-use category ranged from 19 to 29 percent of the standard deviation of the observations.
Performance of the linear regression model of indirect water use was acceptable (table 4 ), with an $R^{2}$ value of 0.89 . The indirect water-use model (fig. $9 B$ ) had a qualitatively better fit than the direct water-use model (fig. 9A), and the dispersion in differences between water-use estimates and observations (fig. 10B) was less than for the direct water-use model (fig. 10A). The regression model of indirect water use had an RMSE value of $0.058 \mathrm{Mgal}$ per well (table 4), or 52 percent of its respective mean coefficient (table 3 ), and the RSR value was 0.29 , which means the RMSE value was 29 percent of the standard deviation of the observations.

Performance of the ancillary water-use model was as acceptable as for the direct and indirect water-use models (table 4), except for one water-use category. Values of $R^{2}$ for the ancillary water-use categories were at least 0.89 , except for domestic water use, which had an $R^{2}$ value of 0.82 . Values of RMSE for the domestic and public-supply ancillary water-use categories were 45 and 54 percent of their respective mean coefficients (table 3). Fit of the ancillary water-use model (for domestic and public supply; fig. 9C) was qualitatively better than fits of the direct (fig. 9A) or indirect (fig. 9B) water-use models. Also, the dispersion in differences between estimated and observed water use for the ancillary water-use model (fig. 10C) was less than for the direct (fig. 10A) or indirect (fig. 10B) water-use models.

Table 4. Goodness-of-fit metrics from leave-one-out cross validation of linear regression models of direct, indirect, and ancillary water use per oil and gas well developed in the Permian Basin.

$\left[R^{2}\right.$, coefficient of determination; RMSE, root mean square error; Mgal, million gallons; RSR, ratio of root mean square error to standard deviation of observations; COG, continuous oil and gas]

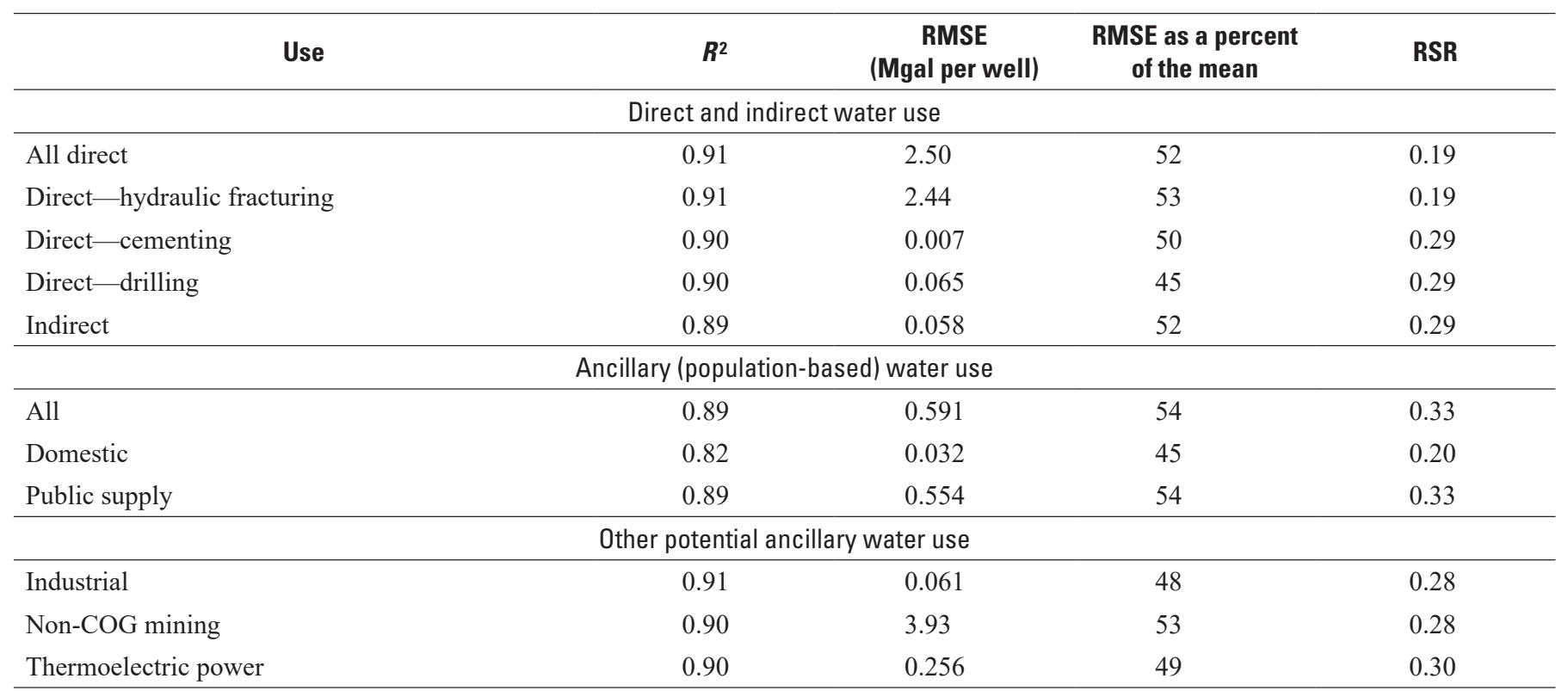



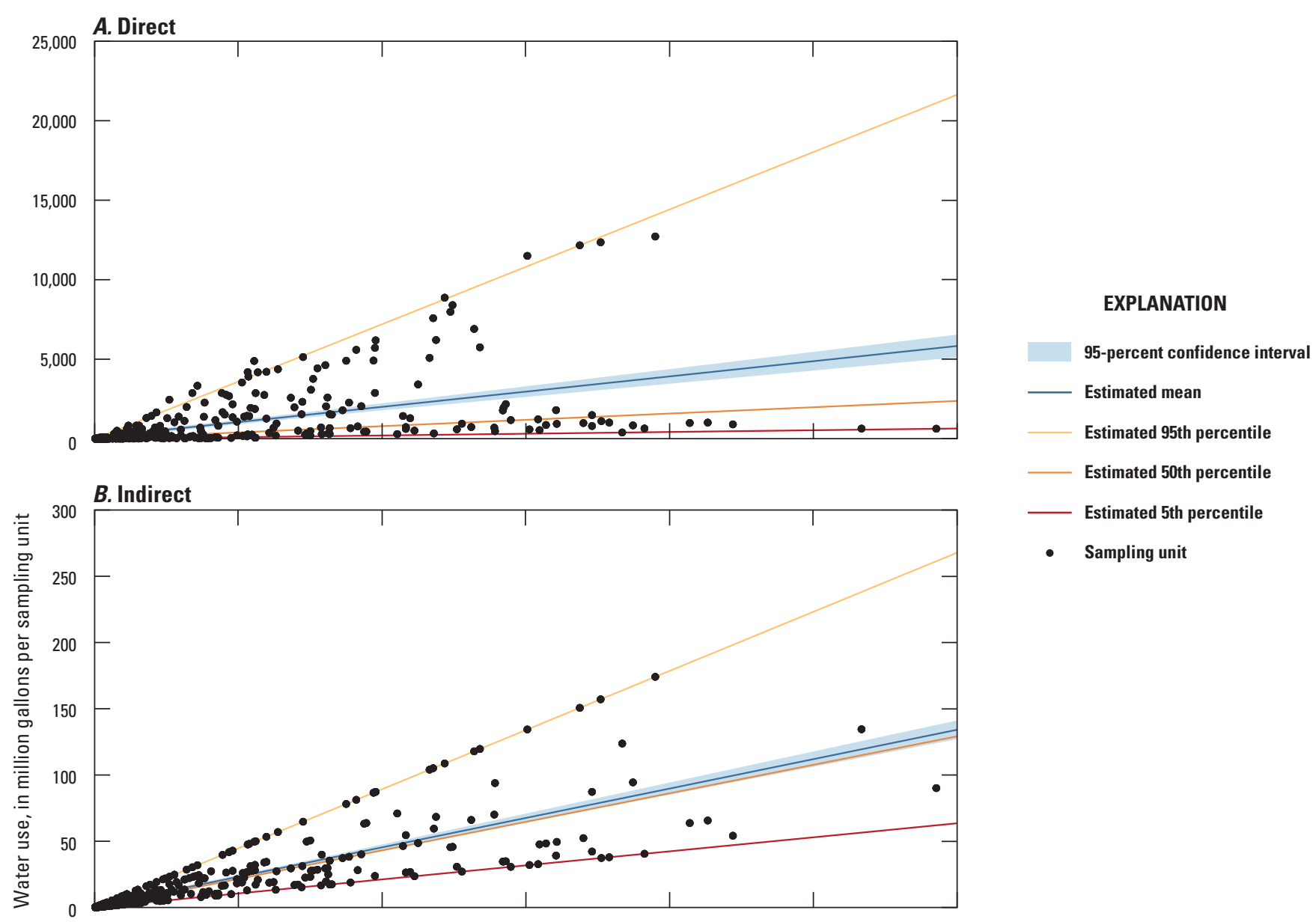

- Sampling unit

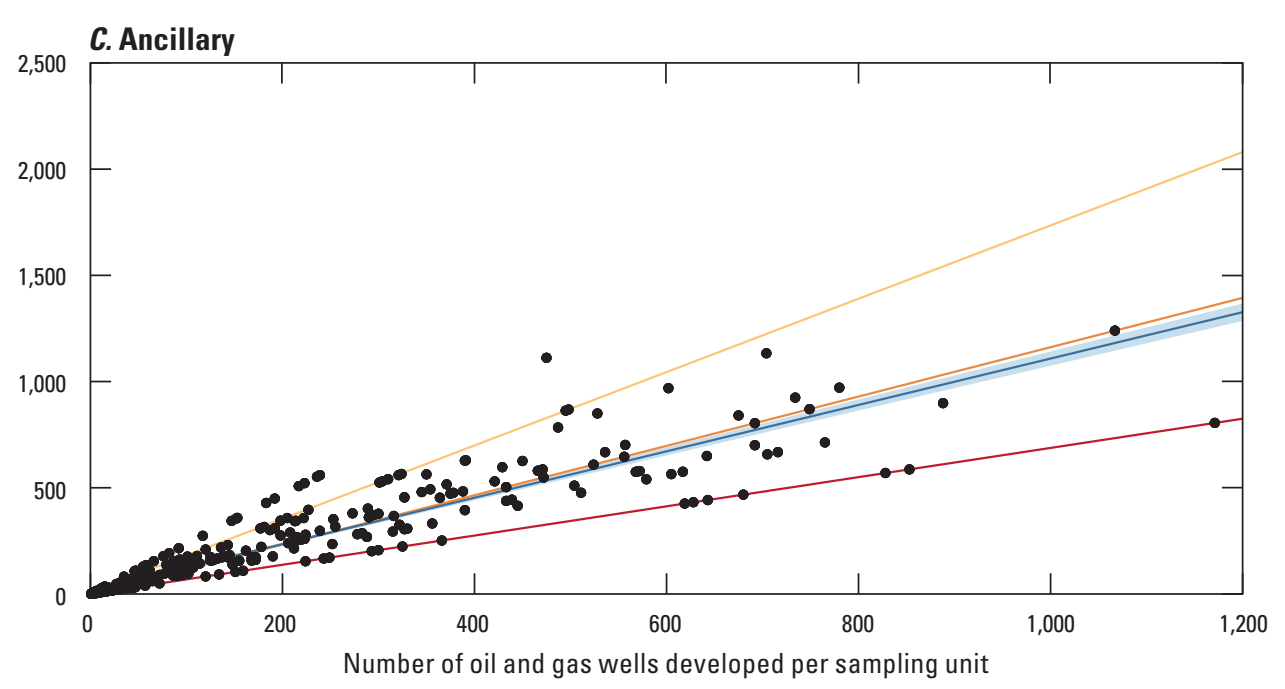

Figure 9. Linear and quantile regression models of $(A)$ direct, $(B)$ indirect, and $(C)$ ancillary water use as explained by number of oil and gas wells developed per sampling unit for the Permian Basin. 

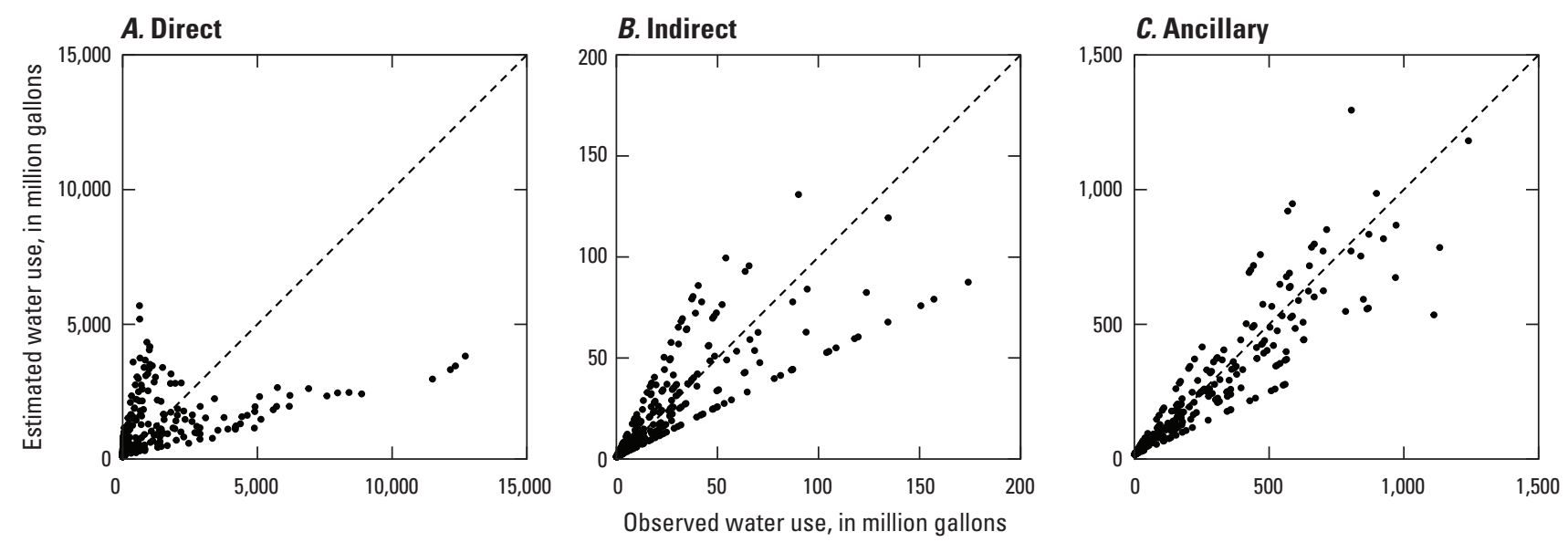

EXPLANATION

-- - - 1:1 line

- Sampling unit

Figure 10. Relation between observed and estimated $(A)$ direct, $(B)$ indirect, and $(C)$ ancillary water use per sampling unit as mean values from linear regression models for the Permian Basin.

\section{Comparisons to Water-Use Estimates from Other Studies}

Estimates from the water-use analysis in this study (table 5) were compared to water-use estimates from other studies (table 6) of per-well estimates of direct water use. Estimates of indirect and ancillary water use related to COG development were not documented in other studies.

Drilling and cementing water use was estimated in this study for 2011 at $0.15 \mathrm{Mgal}$ per well for New Mexico and Texas (table 5; McShane and McDowell, 2021). Estimates of drilling and cementing water-use categories from other studies ranged from 0.084 to $0.42 \mathrm{Mgal}$ per well in the Midland Basin in Texas and from 0.1 to $0.42 \mathrm{Mgal}$ per well in the Delaware Basin in Texas (table 6; Nicot and others, 2012). The similarity between estimates from this study and from the literature validates the methodology used in this study; however, the similarity also may be an artifact of the scanty data available to estimate drilling and cementing water use.

Estimates of hydraulic fracturing water used in this study ranged from 0.30 to $11.98 \mathrm{Mgal}$ per well in New Mexico and from 0.58 to $16.23 \mathrm{Mgal}$ per well in Texas from 2010 to 2019 (table 5; McShane and McDowell, 2021). These values, in comparison to estimates from the literature, are similar during the earlier period in both States but greater during the later period in New Mexico and less during the later period in Texas (table 6). Literature estimates ranged from 0.46 to $10.1 \mathrm{Mgal}$ per well in New Mexico from 2011 to 2018 (table 6; Sullivan Graham and others, 2015; Chen and Carter, 2016; U.S. Department of the Interior, Bureau of Land Management,
2019) and from 1.29 to 17.8 Mgal per well in Texas from 2010 to 2018 (table 6; Chen and Carter, 2016; Backstrom, 2018; Scanlon and others, 2020).

Data from this study and other studies indicate an upward trend in water use per well for hydraulic fracturing in both States. Estimates of hydraulic fracturing water use in the Permian Basin ranged from 0.59 to $15.18 \mathrm{Mgal}$ per well from 2010 to 2018 (McShane and McDowell, 2021). These values are less during earlier periods and similar during later periods in comparison to literature estimates that ranged from 1.29 to $15.5 \mathrm{Mgal}$ per well (table 6; Kondash and others, 2018; Scanlon and others, 2020). This study includes hydraulic fracturing water-use estimates through 2019, with an estimate in 2019 of $16.88 \mathrm{Mgal}$ per well (McShane and McDowell, 2021). Kondash and others (2018) estimated that water use per well for hydraulic fracturing in the Permian Basin increased 770 percent from 2011 to 2016, and Scanlon and others (2020) estimated that it increased 1,458 percent from 2010 to 2018. These percentage increases in water use per well for hydraulic fracturing from the literature are comparable to the estimated 1,430 percent increase from 2010 to 2018 in this study; however, estimates from this study include data from 2019, with an increase from 2010 to 2019 of 1,584 percent. Data from this study and other studies indicate an upward trend in water use per well for hydraulic fracturing in the Permian Basin. Increased water use may be attributed to the increased length of well laterals (the horizontal part of the wellbore; Scanlon and others, 2017) and the changing hydraulic fracturing practices of oil and gas operators. In general, the volume of water required to complete a well increases as the lateral length of the well increases (Scanlon and others, 2017, 2020; Backstrom, 2018). 
Table 5. Annual per-well estimates of direct, indirect, and ancillary water use for the Permian Basin in New Mexico and Texas from 2010 to 2019.

\begin{tabular}{|c|c|c|c|c|c|c|}
\hline \multirow{2}{*}{ Year } & \multirow{2}{*}{ Well count } & \multicolumn{5}{|c|}{ Water use, in million gallons per well } \\
\hline & & Hydraulic fracturing & Cementing & Drilling & Indirect & Ancillary \\
\hline \multicolumn{7}{|c|}{ New Mexico } \\
\hline 2010 & 892 & 0.30 & 0.01 & 0.13 & 0.19 & 1.45 \\
\hline 2011 & 1,074 & 0.58 & 0.01 & 0.14 & 0.12 & 1.40 \\
\hline 2012 & 1,104 & 1.01 & 0.01 & 0.13 & 0.08 & 0.82 \\
\hline 2013 & 1,080 & 1.63 & 0.01 & 0.14 & 0.05 & 1.52 \\
\hline 2014 & 1,140 & 2.84 & 0.01 & 0.15 & 0.06 & 1.89 \\
\hline 2015 & 776 & 4.26 & 0.01 & 0.13 & 0.09 & 1.77 \\
\hline 2016 & 466 & 7.88 & 0.01 & 0.11 & 0.12 & 2.67 \\
\hline 2017 & 634 & 10.81 & 0.01 & 0.12 & 0.08 & 2.38 \\
\hline 2018 & 1,015 & 9.87 & 0.01 & 0.11 & 0.22 & 1.85 \\
\hline 2019 & 928 & 11.98 & 0.01 & 0.12 & 0.24 & 2.57 \\
\hline \multicolumn{7}{|c|}{ Texas } \\
\hline 2010 & 4,028 & 0.58 & 0.01 & 0.14 & 0.16 & 1.21 \\
\hline 2011 & 5,779 & 0.83 & 0.01 & 0.14 & 0.13 & 1.10 \\
\hline 2012 & 7,511 & 1.07 & 0.01 & 0.13 & 0.08 & 0.65 \\
\hline 2013 & 7,251 & 1.64 & 0.01 & 0.12 & 0.05 & 0.77 \\
\hline 2014 & 7,108 & 2.75 & 0.01 & 0.13 & 0.06 & 0.76 \\
\hline 2015 & 4,060 & 5.03 & 0.01 & 0.14 & 0.11 & 1.25 \\
\hline 2016 & 2,611 & 9.26 & 0.01 & 0.14 & 0.15 & 2.20 \\
\hline 2017 & 3,811 & 12.24 & 0.01 & 0.13 & 0.09 & 1.52 \\
\hline 2018 & 4,911 & 14.28 & 0.01 & 0.14 & 0.22 & 1.04 \\
\hline 2019 & 4,418 & 16.23 & 0.01 & 0.14 & 0.22 & 1.29 \\
\hline
\end{tabular}

Water use per well for hydraulic fracturing in the two subbasins in the Permian Basin varied: the Midland Basin and the Delaware Basin had increases of about 2,440 and 1,770 percent, respectively, from 2009 to 2018 (Scanlon and others, 2020). The greater volume of water use in the Midland Basin can be attributed to about 65 percent longer laterals and twice as many hydraulic fracturing stages (segments into which the full hydraulic fracturing treatment is divided) as in the Delaware Basin (Scanlon and others, 2017). Estimates of hydraulic fracturing for the Midland and Delaware Basins were not estimated independently in this study. The use of linear and quantile regression models in this study provided a range of parameter estimates (including mean, median, and 5th and 95th percentiles) of per-well hydraulic fracturing water use based on data from 1980 to 2019 .

Other studies of ancillary or indirect water use were not available for comparison. In a few studies, indirect water use was estimated together with direct water use, which precluded comparison to the independent estimates of indirect water use in this study. 
Table 6. Annual per-well estimates of direct water use associated with continuous oil and gas development in the Permian Basin from other studies. No other studies were found with information on indirect or ancillary water use associated with continuous oil and gas development in the Permian Basin.

[--, none; N/A, not applicable; <, less than; ppm, parts per million; >, greater than; HUC-8, 8-digit hydrologic unit code]

\begin{tabular}{|c|c|c|c|c|c|c|c|}
\hline \multirow[t]{2}{*}{ Water use } & \multicolumn{2}{|c|}{ Study date range } & \multicolumn{2}{|c|}{$\begin{array}{l}\text { Volume per well, } \\
\text { in million gallons }\end{array}$} & \multirow{2}{*}{$\begin{array}{l}\text { Change in water use, } \\
\text { in percent }\end{array}$} & \multirow[t]{2}{*}{ Source } & \multirow[t]{2}{*}{ Comments } \\
\hline & Begin & End & Minimum & Maximum & & & \\
\hline \multicolumn{8}{|c|}{ Direct water use } \\
\hline \multirow[t]{2}{*}{$\begin{array}{l}\text { Drilling, } \\
\text { cementing }\end{array}$} & -- & -- & 0.084 & 0.42 & N/A & Nicot and others, 2012, table 11 & $\begin{array}{l}\text { Midland Basin, range for drilling in Texas provided by } \\
\text { operators. Water categorized as fresh }<3,000 \mathrm{ppm} \text {. }\end{array}$ \\
\hline & -- & -- & 0.1 & 0.42 & N/A & Nicot and others, 2012, table 11 & $\begin{array}{l}\text { Delaware Basin, range for drilling in Texas pro- } \\
\text { vided by operators. Water categorized as brackish } \\
>3,000 \text { ppm. }\end{array}$ \\
\hline \multirow{11}{*}{$\begin{array}{l}\text { Hydraulic } \\
\text { fracturing }\end{array}$} & 2012 & 2016 & 1.53 & 11.78 & +670 & Backstrom, 2018, table 3 & Median value for horizontal wells in Texas. \\
\hline & 2012 & 2013 & 1 & 1.24 & +24 & $\begin{array}{l}\text { Sullivan Graham and others, } 2015 \text {, } \\
\text { table } 2\end{array}$ & $\begin{array}{l}\text { Mean value for Chaves, Eddy, and Lea Counties in } \\
\text { New Mexico. }\end{array}$ \\
\hline & 2011 & 2014 & -- & 1.33 & -- & Gallegos and others, 2015, table S1 & Mean of values of $\mathrm{HUC}-8$ areas in the Permian Basin. \\
\hline & -- & -- & -- & 0.80 & N/A & $\begin{array}{l}\text { Kondash and Vengosh, 2015, table } \\
\text { S1 }\end{array}$ & Median value for oil production (1.05 mean value). \\
\hline & 2011 & 2014 & 0.46 & 1.89 & +311 & Chen and Carter, 2016, table S5 & Mean value for gas production for New Mexico. \\
\hline & 2011 & 2014 & 2.81 & 3.79 & +35 & Chen and Carter, 2016, table S5 & Mean value for gas production for Texas. \\
\hline & 2009 & 2018 & $0.7^{\mathrm{a}}$ & 13.1 & $+1,771$ & Scanlon and others, 2020 , table S9 & Median value for the Delaware Basin, in tight oil. \\
\hline & 2009 & 2018 & $0.7^{\mathrm{a}}$ & 17.8 & $+2,443$ & Scanlon and others, 2020, table S9 & Median value for the Midland Basin, in tight oil. \\
\hline & 2009 & 2018 & $0.7^{\mathrm{a}}$ & 15.5 & $+2,114$ & Scanlon and others, 2020, table S9 & Median value for the Permian Basin, in tight oil. \\
\hline & 2011 & 2016 & 1.29 & 11.24 & +771 & Kondash and others, 2018, table S2 & Median value for the Permian Basin. \\
\hline & -- & 2018 & -- & 10.1 & N/A & $\begin{array}{l}\text { U.S. Department of the Interior, } \\
\text { Bureau of Land Management, } \\
2019\end{array}$ & $\begin{array}{l}\text { Mean value of water use per horizontal well in the } \\
\text { Pecos District (Chaves, Eddy, and Lea Counties in } \\
\text { New Mexico). }\end{array}$ \\
\hline
\end{tabular}

${ }^{\mathrm{a}}$ The values from the Scanlon and others (2020) report for 2010 were compared to the modeled values computed in this study. The 2010 values for hydraulic fracturing water-use per well were $1.2,1.3$, and 1.2 million gallons per day for the Midland Basin, Delaware Basin, and Permian Basin, respectively. The Scanlon and others (2020) report predates this study, and the earliest date is recorded in table 6. 


\section{Comparison with Water-Use Analysis of the Williston Basin}

Data from the Williston Basin (Dutton and others, 2019; McShane and others, 2020) were reanalyzed on an annual basis using the analytical framework as applied to the Permian Basin in this study. This section compares estimates of water use associated with COG development in the Permian Basin and the Williston Basin (fig. 11A, B).

Annual mean estimates for hydraulic fracturing, cementing, drilling, indirect, and ancillary water use per well for the years 2010-17 were comparable in the Permian and Williston Basins. Hydraulic fracturing water use increased similarly from 2010 to 2015, increasing from 1.4 Mgal per well in 2010 to 4.7 Mgal per well in 2015 in the Williston Basin (fig. 11A) and from 0.6 Mgal per well in 2010 to $5.4 \mathrm{Mgal}$ per well in 2015 in the Permian Basin (fig. 11B). However, in 2017, hydraulic fracturing water use was 1.7 times greater in the Permian Basin (14.3 Mgal per well; fig. 11B) than in the Williston Basin (8.4 Mgal per well; fig. 11A). The difference indicates potential differences in the length of well laterals, the hydraulic fracturing practices of operators, the geologic properties of the COG reservoirs, and the supply and cost of surface water or groundwater.

The ranges of estimated cementing and drilling water use per well were similar between the two basins. Cementing water use was 0.014-0.015 Mgal per well in the Williston Basin (fig. 11A) and 0.013-0.016 Mgal per well in the Permian Basin (fig. 11B). Drilling water use was 0.135-0.164 Mgal per well in the Williston Basin (fig. 11A) and 0.132-0.163 Mgal per well in the Permian Basin (fig. 11B). Analyses for the two basins had similar values for cementing and drilling water use despite a difference in the mean depth of wells for the Permian and Williston Basins (8,880 and 12,220 ft, respectively). This difference between the two basins indicates a moderate change in the model assumptions for cementing and drilling water use because available data in the Williston Basin included measured depth of wells, whereas we used true vertical depth for wells in the Permian Basin.

The mean of indirect water use per well for 2010-17 was 82 percent less in the Permian Basin (0.1 Mgal per well) than in the Williston Basin (0.56 Mgal per well). This difference in water use may have resulted from a qualitative difference
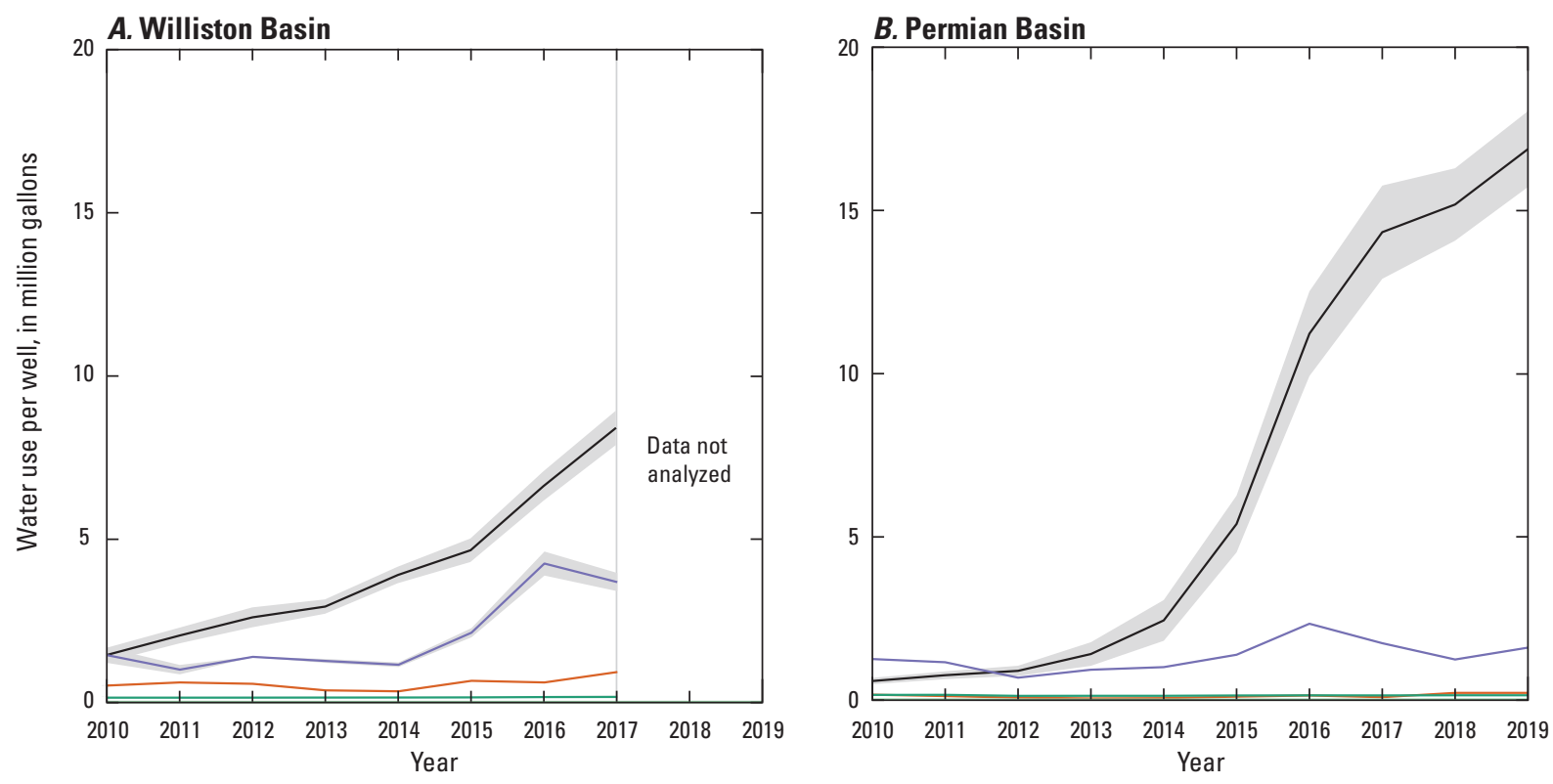

\section{EXPLANATION}

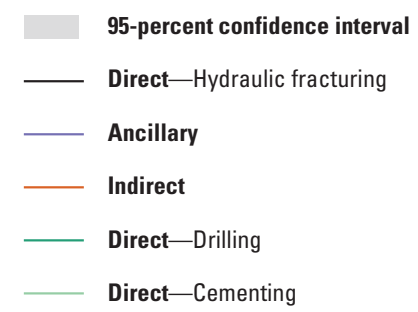

Figure 11. Annual estimates of direct, indirect, and ancillary water use in $(A)$ the Williston Basin from 2010 to 2017 and (B) the Permian Basin from 2010 to 2019. 
between the data sources for the two basins or a difference in water uses at the well site for purposes other than hydraulic fracturing, cementing, and drilling.

The estimated range of ancillary water use per well for 2010-17 was less in the Permian Basin (0.7-2.3 Mgal per well; fig. $8 A$ ) than in the Williston Basin (1-4.3 Mgal per well), which may indicate a difference between the two basins in water used through public supply or domestically (selfsupply) that is unrelated to COG development. Additionally, it may indicate a difference between the two basins in the relation of population-based ancillary water use and COG development. Linear regression modeling indicated that population growth changes lagged 2 years behind the number of oil and gas wells developed in the Williston Basin, but in the Permian Basin, the lag was 5 years. This difference in lag indicates a weaker correlation between population growth and $\mathrm{COG}$ development in the Permian Basin. Additionally, the population of the Permian Basin was already established during historical and ongoing conventional oil and gas development and was more stable during oil and gas booms and busts than for the more remote Williston Basin.

\section{Limitations of Water-Use Analysis of the Permian Basin}

The assessment of water use in the Permian Basin is a simplification of a complex and continually developing real-world system and therefore has limitations in the methods used for analyzing the data and in the interpretation of the results. The water-use analysis of the Permian Basin had several limitations that potentially affected the accuracy of water-use estimates associated with COG development in the Permian Basin. In addition to the limitations described in this report, Valder and others $(2018,2019)$ describe general limitations in the conceptualization and framing of an assessment of water use associated with the life cycle of COG development. Additionally, McShane and others (2020) describe specific limitations in the water-use data and water-use methodology used in an analysis, which collectively formed the basis for this study.

Limitations of the water-use analysis of the Permian Basin were similar to the limitations of the water-use analysis of the Williston Basin (McShane and others, 2020). These limitations included (1) greater uncertainty in the coefficients from the regression models of cementing and drilling water use than hydraulic fracturing water use because of limited data availability and necessary assumptions about water use based on well depth and diameter; (2) an implied assumption in the regression models of the ancillary water-use categories that changes in domestic, public-supply, industrial, non-COG mining, and thermoelectric power water use were related to $\mathrm{COG}$ development; (3) the capacity of the confidence interval for the coefficient from the linear regression model to adequately capture the data variance; (4) the key assumption of estimating a breakpoint (year) in the hydraulic fracturing water-use data because selection of a different year would have affected the estimates of indirect and ancillary water use; (5) the appropriateness of the goodness-of-fit metrics and validation procedures used for this study to evaluate uncertainty in the water-use estimates and performance of the linear and quantile regression models; and (6) the ability of the simple linear and quantile regression models used for this study to explain water use associated with COG development.

Another limitation of the water-use analysis of the Permian Basin was the assumption that water-use data from Texas used to estimate indirect water use were applicable to New Mexico, which lacked data for estimating indirect water use. This limitation was the same as for the water-use analysis of the Williston Basin (McShane and others, 2020) with data from North Dakota applied to Montana for estimating indirect water use.

Despite modeling limitations, the results of this report compare well with water-use estimates from other studies. The favorable comparison supports the transferability of the methods used to analyze water use to other areas of COG development.

\section{Summary}

In 2015, the U.S. Geological Survey started a topical study focused on quantifying water use in areas of continuous oil and gas (COG) development. This topical study to quantify water use related to COG development will help achieve that U.S. Geological Survey Water Availability and Use Science Program goal. The first phase of the study was completed in 2019 and analyzed the Williston Basin in North Dakota and Montana. The second phase of the study analyzed the Permian Basin in Texas and New Mexico using the same techniques and approaches used for the Williston Basin analysis. The Permian Basin was selected for the second phase of water-use analysis for the following reasons: (1) it has the largest undiscovered technically recoverable oil and gas resource in the United States, (2) it has a continuous resource in tight shale that primarily produces oil, and (3) its boundary is within the contiguous United States.

The Permian Basin is a large carbonate and clastic sedimentary basin that extends across western Texas and southeastern New Mexico, covering more than 75,000 square miles. This study assesses data from 60 counties in Texas and New Mexico with a spatial coverage closely following the U.S. Energy Information Administration's Permian Basin extent, a representation of the geologically defined Permian Basin.

The analysis of water use associated with COG development presented in this report was based on prior methodological development. Supporting the initial application of the 
analytical framework in the water-use analysis of the Williston Basin, the analytical framework was applied to the Permian Basin in Texas and New Mexico.

Data from several sources were processed for use in the analysis of direct, indirect, and ancillary water use associated with COG development in the Permian Basin and are available in an associated data release. Hydraulic fracturing water-use data were used to determine when COG development (rather than conventional oil and gas) began the most recent (before 2019) boom in oil production in the Permian Basin in the same way as in the Williston Basin study. Water-use data were aggregated by county and year, which were the sampling units used in this analysis. Direct water use, for example, cementing and drilling, were estimated from available data on depth per well. Indirect water use was estimated from available data on water use from point and nonpoint sources.

Most procedures used for modeling water use and uncertainty in this study also followed the procedures used in the Williston Basin study. The water-use analysis of the Permian Basin contains three elements: (1) estimates of water use, in million gallons, by county and year; (2) coefficients of water use from the regression models, in million gallons per developed oil and gas well; and (3) performance (based on goodness-of-fit metrics) of the regression models in estimating (predicting) the observed water use. Mean annual direct and indirect water use for COG development in the Permian Basin was estimated at 33,777 million gallons per year (Mgal/yr), with a 95-percent confidence interval of 33,258-34,319 Mgal/yr. Hydraulic fracturing accounted for 95 percent of direct and indirect water use. Ancillary water use (for domestic and public supply) had an estimated annual mean of 7,386 Mgal/yr in the Permian Basin. Direct water use had an upward trend that in 2019 reached $72,220 \mathrm{Mgal} / \mathrm{yr}$ in Texas and 11,403 Mgal/yr in New Mexico, 6.3 times more in Texas than in New Mexico. From 2010 to 2019, mean annual direct water use was 28,732 Mgal/yr in Texas and 4,326 Mgal/ $\mathrm{yr}$ in New Mexico. Mean annual ancillary water use from 2010 to 2019 was 5,068 Mgal/yr in Texas and 2,318 Mgal/ $\mathrm{yr}$ in New Mexico. Estimates of water use by county and year used in the analyses for Texas and New Mexico are available in an associated data release. These estimates include direct and indirect water use (COG mining) and ancillary water use for the domestic, public-supply, industrial, non-COG mining, and thermoelectric power categories. Ancillary water use for the domestic and public-supply categories (population based) is directly related to COG development, whereas the other potential ancillary water-use categories (industrial, non-COG mining, or thermoelectric power) are indirectly associated with COG development.

Coefficients from the linear and quantile regression models of direct, indirect, and ancillary water use in the Permian Basin were produced as aggregate values across all counties and over all years in the analysis. The mean estimate of direct water use had a 95-percent confidence interval of 4.13-5.45 million gallons (Mgal) per well. The coefficient from the linear regression model of indirect water use was
0.111 Mgal per well, with a 95-percent confidence interval of $0.104-0.117 \mathrm{Mgal}$ per well. The mean estimate of ancillary water use (for domestic and public supply) in the Permian Basin was 1.09 Mgal per well, with a 95-percent confidence interval of 1.05-1.13 Mgal per well.

Model performance was evaluated with goodness-of-fit metrics (coefficient of determination $\left[R^{2}\right]$, root mean square error, and the ratio of root mean square error to standard deviation of observations) computed from leave-one-out cross validation of the linear and quantile regression models of direct, indirect, and ancillary water use. Model performance for direct water use was acceptable, with an $R^{2}$ value of 0.91 . The model performance of indirect water use was acceptable, with an $R^{2}$ value of 0.89 . Values of $R^{2}$ for the ancillary water-use categories were at least 0.82 . Estimates from the water-use analysis in this study were compared to water-use estimates from other studies of per-well water use for direct water use and ancillary water use (for domestic and public supply). Estimates of indirect water use related to COG development were not documented in other studies. The similarities between water-use estimates in this study and from other studies provide validation of the methods used to analyze water use in this study.

Annual mean estimates for hydraulic fracturing, cementing, drilling, indirect, and ancillary water use per well for the years 2010-17 were comparable in the Permian and Williston Basins. Hydraulic fracturing water use had increased similarly from 2010 to 2015 in the Permian and Williston Basins, increasing from 0.6 Mgal per well in 2010 to $5.4 \mathrm{Mgal}$ per well in 2015 in the Permian Basin and from 1.4 Mgal per well in 2010 to 4.7 Mgal per well in 2015 in the Williston Basin.

Modeling and analysis of water use in areas of COG development are a numeric approximation of a complex and often uncertain physical system. The Permian water-use assessment is, by design, a simplification of the complex and continuously developing system and, as a result, contains uncertainty and limitations in the interpretation of the results. Despite the modeling limitations, the results summarized within the report, when compared to other studies, compare well with water-use estimations. The favorable comparison highlights the transferability of the water-use methodology to other areas of COG development.

\section{References Cited}

American Oil and Gas Historical Society, 2020, This week in petroleum history, September 14 to September 20: American Oil and Gas Historical Society web page, accessed June 8, 2020, at https://www.aoghs.org/this-weekin-petroleum-history/september-14-2020/.

Backstrom, J., 2018, Groundwater regulations and hydraulic fracturing-Reporting water use in the Permian: College Station, Texas, Texas A\&M University, Ph.D. dissertation, $34 \mathrm{p}$. 
Ball, G.P., Galanter, A.E., McDowell, J.S., Houston, N.A., McShane, R.R., Haines, S., Varela, B., Valder, J.F., and Thamke, J.N., 2020, Data to estimate water use associated with continuous oil and gas development, Permian Basin, United States, 1980-2019: U.S. Geological Survey data release, accessed May 29, 2021, at https://doi.org/10.5066/P9LAWIPH.

Barker, R.A., and Ardis, A.F., 1996, Hydrogeologic framework of the Edwards-Trinity aquifer system, west-central Texas: U.S. Geological Survey Professional Paper 1421-B, 61 p. [Also available at https://doi.org/10.3133/pp1421B.]

Barroll, P., and Shomaker, J., 2003, Regional hydrology of the Roswell Artesian Basin and the Capitan aquifer, in Johnson, P.S., Land, L.A., Price, L.G., and Titus, F., eds., Water resources of the lower Pecos region, New Mexico: New Mexico Bureau of Geology and Mineral Resources, 2003 New Mexico Decision Makers Guidebook, p. 23-27.

Broadhead, R.F., 2017, Energy and mineral resources of New Mexico: Petroleum Geology, New Mexico Bureau of Geology and Mineral Resources, Memoir 50A, 104 p. [Also available at https:/geoinfo.nmt.edu/publications/ monographs/memoirs/50/A/.]

Bureau of Economic Geology, 2008, Integrated synthesis of the Permian Basin project GIS data: Bureau of Economic Geology digital data, accessed May 28, 2020, at https:/ /www.beg.utexas.edu/resprog/permianbasin/gis_data/ PBGSP_GIS.zip.

Carter, J.M., Macek-Rowland, K.M., Thamke, J.N., and Delzer, G.C., 2016, Estimating national water use associated with unconventional oil and gas development: U.S. Geological Survey Fact Sheet 2016-3032, 6 p. [Also available at https://doi.org/10.3133/fs20163032.]

Chen, H., and Carter, K.E., 2016, Water usage for natural gas production through hydraulic fracturing in the United States from 2008 to 2014: Journal of Environmental Management, v. 170, p. 152-159. [Also available at https://doi.org/ 10.1016/j.jenvman.2016.01.023.]

Dancy, J.R., 2018, From the Drake well to the Santa Rita \#1-The history of the U.S. Permian Basin-A miracle of technological innovation: Oil \& Gas, Natural Resources, and Energy Journal, v. 3, no. 5, art. 1183. [Also available at https://digitalcommons.law.ou.edu/onej/vol3/iss5/3.]

Dieter, C.A., Maupin, M.A., Caldwell, R.R., Harris, M.A., Ivahnenko, T.I., Lovelace, J.K., Barber, N.L., and Linsey, K.S., 2018, Estimated use of water in the United States in 2015: U.S. Geological Survey Circular 1441, 65 p. [Also available at https://doi.org/10.3133/cir1441.]
Dutton, D.M., Varela, B., Haines, S.S., Barnhart, T.B., McShane, R.R., and Wheeling, S.L., 2019, Data to estimate water use associated with continuous oil and gas development, Williston Basin, United States, 1980-2017 (ver. 2.0, September 2019): U.S. Geological Survey data release, accessed October 6, 2020, at https://doi.org/10.5066/ P9CPKRLW.

Engle, M.A., Reyes, R.R., Varonka, M.S., Orem, W.H., Ma, L., Ianno, A.J., Schell, T.M., Xu, P., and Carroll, K.C., 2016, Geochemistry of formation waters from the Wolfcamp and "Cline" shales - Insights into brine origin, reservoir connectivity, and fluid flow in the Permian Basin, USA: Chemical Geology, v. 425, p. 76-92. [Also available at https://doi.org/ 10.1016/j.chemgeo.2016.01.025.]

FracFocus, 2020, FracFocus Chemical Disclosure Registry: FracFocus database, accessed May 28, 2020, at https://frac focus.org/data-download.

Gallegos, T.J., Varela, B.A., Haines, S.S., and Engle, M.A., 2015, Hydraulic fracturing water use variability in the United States and potential environmental implications: Water Resources Research, v. 51, no. 7, p. 5839-5845. [Also available at https://doi.org/10.1002/2015WR017278.]

Garber, R.A., and Harris, P.M., 1986, Depositional facies of Grayburg/San Andres dolomite reservoirs, Central Basin Platform, Permian Basin, in Bebout, D.G., and Harris, P.M., eds., Geologic and engineering approaches in evaluation of San Andres/Grayburg hydrocarbon reservoirs_-Permian Basin: University of Texas Bureau of Economic Geology Symposium SP 5, p. 61-66.

Gaswirth, S.B., French, K.L., Pitman, J.K., Marra, K.R., Mercier, T.J., Leathers-Miller, H.M., Schenk, C.J., Tennyson, M.E., Woodall, C.A., Brownfield, M.E., Finn, T.M., and Le, P.A., 2018, Assessment of undiscovered continuous oil and gas resources in the Wolfcamp shale and Bone Spring Formation of the Delaware Basin, Permian Basin Province, New Mexico and Texas, 2018: U.S. Geological Survey Fact Sheet 2018-3073, 4 p. [Also available at https://doi.org/10.3133/fs20183073.]

Gaswirth, S.B., Marra, K.R., Lillis, P.G., Mercier, T.J., Leathers-Miller, H.M., Schenk, C.J., Klett, T.R., Le, P.A., Tennyson, M.E., Hawkins, S.J., Brownfield, M.E., Pitman, J.K., and Finn, T.M., 2016, Assessment of undiscovered continuous oil resources in the Wolfcamp shale of the Midland Basin, Permian Basin Province, Texas, 2016: U.S. Geological Survey Fact Sheet 2016-3092, 4 p. [Also available at https://doi.org/10.3133/fs20163092.]

George, P.G., Mace, R.E., and Petrossian, R., 2011, Aquifers of Texas: Austin, Texas, Texas Water Development Board Report 380, 172 p. [Also available at http://www.twdb. texas.gov/publications/reports/numbered_reports/doc/ R380_AquifersofTexas.pdf.] 
Harper, J.A., 2008, The Marcellus Shale-An old "new" gas reservoir, in Pennsylvania Geology: Pennsylvania Department of Conservation and Natural Resources, v. 38, no. $1,20 \mathrm{p}$.

Hastie, T., Tibshirani, R., and Friedman, J., 2009, The elements of statistical learning-Data mining, inference, and prediction (2d ed.): New York, Springer, 745 p.

IHS Markit ${ }^{\mathrm{TM}}, 2020$, U.S. well database: IHS Markit ${ }^{\mathrm{TM}}$ web page, accessed August 27, 2020, at https://ihsMarkit.com/ industry/oil-gas.html.

Jiang, M., Hendrickson, C.T., and VanBriesen, J.M., 2014, Life cycle water consumption and wastewater generation impacts of a Marcellus shale gas well: Environmental Science \& Technology, v. 48, no. 3, p. 1911-1920. [Also available at https://doi.org/10.1021/es4047654.]

Kenny, J.F., Barber, N.L., Hutson, S.S., Linsey, K.S., Lovelace, J.K., and Maupin, M.A., 2009, Estimated use of water in the United States in 2005: U.S. Geological Survey Circular 1344, 52 p. [Also available at https://doi.org/ 10.3133/cir1344.]

Koenker, R., 2018, quantreg-Quantile regression (ver. 5.38): R package, accessed July 2018 at https://cran.r-project.org/ web/packages/quantreg/.

Kondash, A.J., Lauer, N.E., and Vengosh, A., 2018, The intensification of the water footprint of hydraulic fracturing: Science Advances, v. 4, no. 8, art. eaar5982. [Also available at https://doi.org/10.1126/sciadv.aar5982.]

Kondash, A., and Vengosh, A., 2015, Water footprint of hydraulic fracturing: Environmental Science \& Technology Letters, v. 2, no. 10, p. 276-280. [Also available at https://doi.org/10.1021/acs.estlett.5b00211.]

Legates, D.R., and McCabe, G.J., Jr., 1999, Evaluating the use of "goodness-of-fit" measures in hydrologic and hydroclimatic model validation: Water Resources Research, v. 35, no. 1, p. 233-241. [Also available at https://doi.org/10.1029/ 1998WR900018.]

Levine, S., Sigmon, R., and Douglas, S., 2002, Yates FieldSuper giant of the Permian Basin: Houston Geological Society Bulletin, v. 45, no. 3, p. 39-51, accessed May 8, 2020, at https://archives.datapages.com/data/HGS/vol45/ no03/39.htm.

Marra, K.R., Gaswirth, S.B., Schenk, C.J., Leathers-Miller, H.M., Klett, T.R., Mercier, T.J., Le, P.A., Tennyson, M.E., Finn, T.M., Hawkins, S.J., and Brownfield, M.E., 2017, Assessment of undiscovered oil and gas resources in the Spraberry Formation of the Midland Basin, Permian Basin Province, Texas, 2017: U.S. Geological Survey Fact Sheet 2017-3029, 2 p. [Also available at https://doi.org/10.3133/ fs20173029.]
Matchus, E.J., and Jones, T.S., 1984, East-west cross section through Permian Basin of west Texas: West Texas Geological Society, scale 1:250,000.

Maupin, M.A., Kenny, J.F., Hutson, S.S., Lovelace, J.K., Barber, N.L., and Linsey, K.S., 2014, Estimated use of water in the United States in 2010: U.S. Geological Survey Circular 1405, 56 p. [Also available at https://doi.org/ 10.3133/cir1405.]

McShane, R.R., Barnhart, T.B., Valder, J.F., Haines, S.S., Macek-Rowland, K.M., Carter, J.M., Delzer, G.C., and Thamke, J.N., 2020, Estimates of water use associated with continuous oil and gas development in the Williston Basin, North Dakota and Montana, 2007-17: U.S. Geological Survey Scientific Investigations Report 2020-5012, 26 p. [Also available at https://doi.org/10.3133/sir20205012.]

McShane, R.R., and McDowell, J.S., 2021, R scripts and results of estimated water use associated with continuous oil and gas development, Permian Basin, United States, 2010-19: U.S. Geological Survey data release, https://doi.org/10.5066/P9JIOU3V.

Moriasi, D.N., Arnold, J.G., Van Liew, M.W., Bingner, R.L., Harmel, R.D., and Veith, T.L., 2007, Model evaluation guidelines for systematic quantification of accuracy in watershed simulations: Transactions of the ASABE, v. 50, no. 3, p. 885-900. [Also available at https://doi.org/ 10.13031/2013.23153.]

Muggeo, V.M.R., 2018, segmented-Regression models with break-points/change-points estimation (ver. 0.5-3.0): $\mathrm{R}$ package, accessed July 2018 at https://cran.r-project.org/ web/packages/segmented/.

New Mexico Oil Conservation Division, 2020, Natural gas and oil production: New Mexico Oil Conservation Division digital data, accessed November 13, 2020, at https://wwwapps.emnrd.state.nm.us/ocd/ocdpermitting/ Reporting/Production/ProductionInjectionSummaryR eport.aspx.

Nicot, J., Reedy, R.C., Costley, R.A., and Huang, Y., 2012, Oil \& gas water use in Texas - Update to the 2011 mining water use report: Bureau of Economic Geology, 97 p., accessed November 21, 2019, at http://www.twdb.texas.gov/ publications/reports/contracted_reports/doc/0904830939_ 2012Update_MiningWaterUse.pdf.

PRISM Climate Group, 2020, PRISM climate data: PRISM Climate Group web page, accessed September 6, 2020, at https://prism.oregonstate.edu.

R Core Team, 2020, R-A language and environment for statistical computing (ver. 4.0.2): Vienna, Austria, R Foundation for Statistical Computing, accessed June 22, 2020, at https://www.r-project.org/. 
Railroad Commission of Texas, 2019, Historical crude oil production and well counts (since 1935): Railroad Commission of Texas web page, accessed November 2, 2020, at https:// www.rrc.state.tx.us/oil-and-gas/research-and-statistics/ production-data/historical-production-data/crude-oilproduction-and-well-counts-since-1935.

Robson, S.G., and Banta, E.R., 1995, Ground water atlas of the United States-Segment 2, Arizona, Colorado, New Mexico, Utah: U.S. Geological Survey Hydrologic Atlas 730-C, 32 p. [Also available at https://doi.org/ 10.3133/ha730C.]

Ryder, P.D., 1996, Ground water atlas of the United States-Segment 4, Oklahoma, Texas: U.S. Geological Survey Hydrologic Atlas 730-E, 30 p. [Also available at https://doi.org/10.3133/ha730E.]

Scanlon, B.R., Ikonnikova, S., Yang, Q., and Reedy, R.C., 2020, Will water issues constrain oil and gas production in the United States?: Environmental Science \& Technology, v. 54, no. 6, p. 3510-3519. [Also available at https://doi.org/ 10.1021/acs.est.9b06390.]

Scanlon, B.R., Reedy, R.C., Male, F., and Walsh, M., 2017, Water issues related to transitioning from conventional to unconventional oil production in the Permian Basin: Environmental Science \& Technology, v. 51, no. 18, p. 10903-10912. [Also available at https://doi.org/10.1021/ acs.est.7b02185.]

Schenk, C.J., Tennyson, M.E., Klett, T.R., Mercier, T.J., Brownfield, M.E., Gaswirth, S.B., Hawkins, S.J., LeathersMiller, H.M., Marra, K.R., Finn, T.M., and Pitman, J.K., 2016, Assessment of tight-gas resources in Canyon sandstones of the Val Verde Basin, Texas, 2016: U.S. Geological Survey Fact Sheet 2016-3039, 2 p. [Also available at https://doi.org/10.3133/fs20163039.]

Schmoker, J.W., 2005, U.S. Geological Survey assessment concepts for continuous petroleum accumulations, chap. 13 of Petroleum systems and geologic assessment of oil and gas in the Southwestern Wyoming Province, Wyoming, Colorado, and Utah: U.S. Geological Survey Data Series 69-D, 7 p. [Also available at https://doi.org/ 10.3133/ds69D.]

Schmoker, J.W., and Klett, T.R., 2005, U.S. Geological Survey assessment concepts for conventional petroleum accumulations, chap. 19 of Petroleum systems and geologic assessment of oil and gas in the Southwestern Wyoming Province, Wyoming, Colorado, and Utah: U.S. Geological Survey Data Series 69-D, 6 p. [Also available at https://doi.org/ 10.3133/ds69D.]
Standen, A., Finch, S., Williams, R., and Lee-Brand, B., 2009, Capitan Reef Complex - Structure and stratigraphy: Texas Water Development Board, Contract no. 0804830794, 12 p., accessed August 11, 2021, at https://www.nrc.gov/ docs/ML1030/ML103080934.pdf. [Errata published December 2009 and available at https://www.twdb. texas.gov/publications/reports/contracted_reports/doc/08 04830794CapitanReef/0804830794CapitanReef_Errata 12-14-09.pdf.]

Sullivan Graham, E.J., Jakle, A.C., and Martin, F.D., 2015, Reuse of oil and gas produced water in south-eastern New Mexico-Resource assessment, treatment processes, and policy: Water International, v. 40, no. 5-6, p. 809-823, accessed July 22, 2020, at https://doi.org/10.1080/0 2508060.2015 .1096126 .

Texas Water Development Board, 2020, Historical water use estimates: Texas Water Development Board web page, accessed June 19, 2019, at http://www.twdb.texas.gov/ waterplanning/waterusesurvey/estimates/index.asp.

U.S. Census Bureau, 2020, Intercensal state and county population estimates: U.S. Census Bureau digital data, accessed September 6, 2020, at https://www2.census.gov/programssurveys/popest/tables/.

U.S. Department of the Interior, Bureau of Land Management, 2019, 2019 BLM New Mexico water support document: U.S. Department of the Interior, Bureau of Land Management, 58 p., accessed July 5, 2020, at https://www.blm.gov/sites/blm.gov/files/2019\% 20BLM\%20NM\%20Water\%20Support\%20Document 07122019_508.pdf.

U.S. Energy Information Administration, 2017, Permian Basin-Boundary, structure, and tectonic features: U.S. Energy Information Administration digital data, accessed May 28, 2020, at https:/www.eia.gov/maps/map_data/ PermianBasin_Boundary_Structural_Tectonic.zip.

U.S. Energy Information Administration, 2020a, New Mexico State profile and energy estimates: U.S. Energy Information Administration web page, accessed May 28, 2020, at https://www.eia.gov/state/?sid=NM\#tabs-3.

U.S. Energy Information Administration, 2020b, Texas State profile and energy estimates: U.S. Energy Information Administration web page, accessed May 28, 2020, at https://www.eia.gov/state/?sid=TX\#tabs-3.

U.S. Energy Information Administration, 2020c, Permian Basin-Part 1-Wolfcamp, Bone Spring, Delaware shale plays of the Delaware Basin-Geology review: Washington, D.C., U.S. Department of Energy, 38 p. [Also available at https://www.eia.gov/maps/pdf/Permian-pI_WolfcampBonespring-Delaware.pdf.] 
U.S. Geological Survey, 2013, USGS hill shade base map service from The National Map: U.S. Geological Survey digital data, accessed June 9, 2021, at https://www.scienc ebase.gov/catalog/item/544172ece4b0b0a643c73c75.

U.S. Geological Survey, 2020, USGS water data for the Nation: U.S. Geological Survey National Water Information System database, accessed March 2020 at https://doi.org/ 10.5066/F7P55KJN.
Valder, J.F., McShane, R.R., Barnhart, T.B., Sando, R., Carter, J.M., and Lundgren, R.F., 2018, Conceptual model to assess water use associated with the life cycle of unconventional oil and gas development: U.S. Geological Survey Scientific Investigations Report 2018-5027, 22 p, accessed June 4, 2021, at https://doi.org/10.3133/sir20185027.

Valder, J.F., McShane, R.R., Barnhart, T.B., Wheeling, S.L., Carter, J.M., Macek-Rowland, K.M., Delzer, G.C., and Thamke, J.N., 2019, Analytical framework to estimate water use associated with continuous oil and gas development: U.S. Geological Survey Scientific Investigations Report 2019-5100, 19 p, accessed May 22, 2021, at https://doi.org/ 10.3133/sir20195100. 

For more information about this publication, contact: Director, USGS Dakota Water Science Center

821 East Interstate Avenue, Bismarck, ND 58503

1608 Mountain View Road, Rapid City, SD 57702

605-394-3200

For additional information, visit: https://www.usgs.gov/centers/ dakota-water

Publishing support provided by the

Rolla Publishing Service Center 


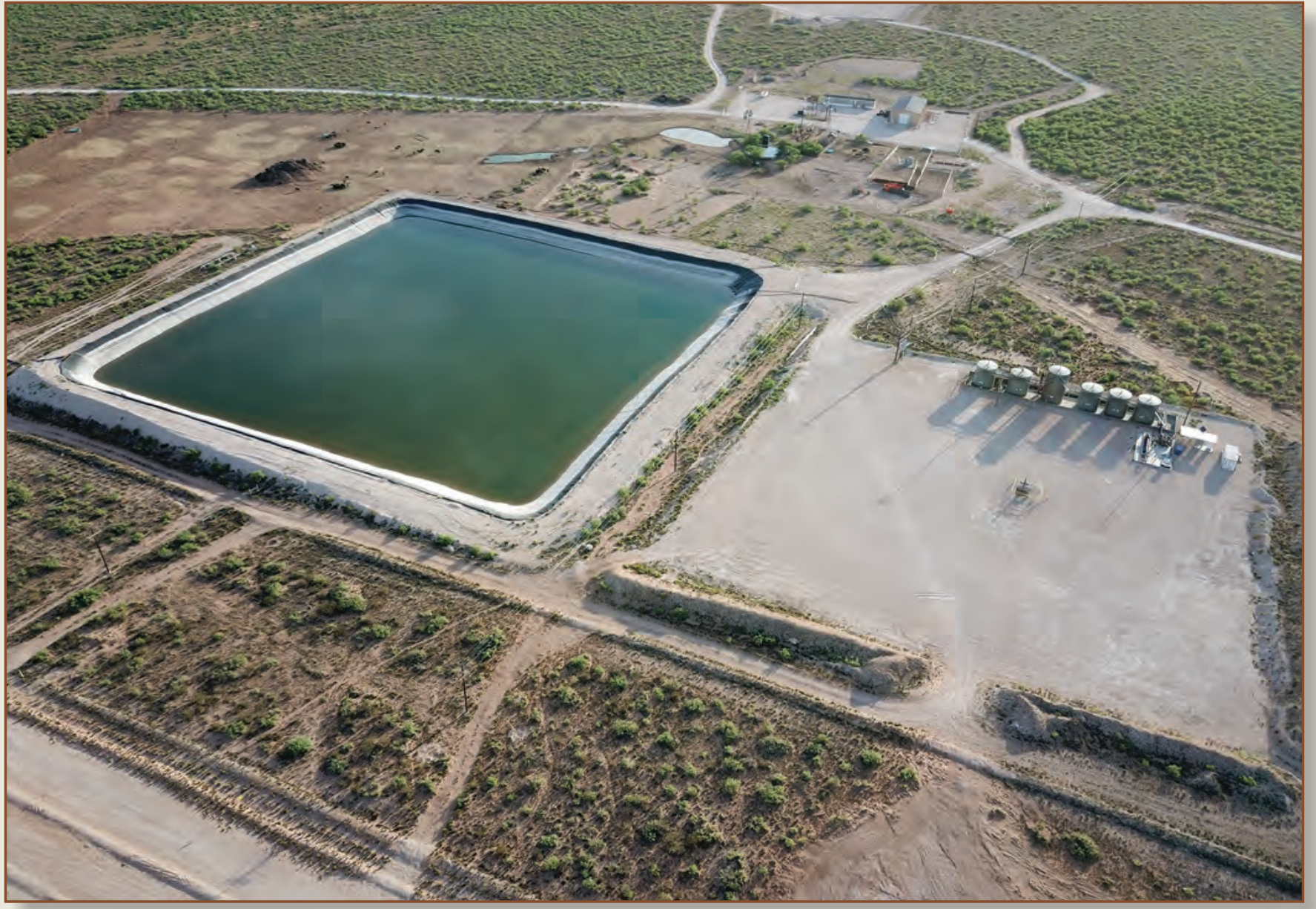

